\title{
IDENTIFICATION AND CHARACTERIZATION OF VOLTAGE- SENSITIVE CALCIUM CHANNELS IN NEURONAL CLONAL CELL LINES ${ }^{1}$
}

\author{
STEPHEN B. FREEDMAN, GLYN DAWSON, MITCHFI، I. VII. FRFAL, AND RICHARD J. MILLER ${ }^{2}$
}

Department of Pharmacological and Physiological Sciences, The University of Chicago, Chicago, Illinois 60637

Received September 8, 1983; Accepted December 2, 1983

\begin{abstract}
Voltage-sensitive calcium channels (VSCCs) have been identified in three clonal cell lines. These are the neuroblastoma $\times$ Chinese hamster brain hybrid $(\mathrm{NCB}-20)$, the neuroblastoma $\times$ glioma hybrid (NG108-15), and the neuroblastoma (N4TG1). Depolarization of NCB-20 cells with $50 \mathrm{~mm}$ $\mathrm{KCl}$ or $50 \mu \mathrm{M}$ veratridine (VE) produced a 2- to 3 -fold increase in net ${ }^{45} \mathrm{Ca}^{2+}$ uptake. In NCB-20 cells, this voltage-sensitive ${ }^{45} \mathrm{Ca}^{2+}$ uptake was inhibited selectively by organic calcium antagonists such as nitrendipine, cinnarizine, verapamil, and diltiazem $\left(\mathrm{IC}_{50}\right.$ values $=6.4,750,1800$, and 4500 $\mathrm{nM}$, respectively). High $\mathrm{K}^{+}$-induced uptake was unaffected by 4 -aminopyridine, tetraethylammonium, and tetrodotoxin (TTX), whereas VE-induced ${ }^{45} \mathrm{Ca}^{2+}$ uptake was completely blocked by $3 \mu \mathrm{M}$ TTX. In contrast to NCB-20 cells, NG108-15 cells showed a much smaller response to depolarizing stimuli. Following differentiation of NG108-15 cells by chronic treatment with $10 \mu \mathrm{M}$ prostaglandin $\mathrm{E}_{1}$ and $50 \mu \mathrm{M}$ 3-isobutyl-1-methylxanthine, depolarization induced a large increase in voltagesensitive ${ }^{45} \mathrm{Ca}^{2+}$ uptake. This induction was apparent after $24 \mathrm{hr}$ and increased linearly for $96 \mathrm{hr}$. VSCC activity was also induced by $1.5 \%$ dimethyl sulfoxide and by other agents that increase intracellular cAMP, such as forskolin $(1 \mu \mathrm{M})$ and cholera toxin $(1 \mu \mathrm{g} / \mathrm{ml})$. Voltage-sensitive ${ }^{45} \mathrm{Ca}^{2+}$ uptake in differentiated NG108-15 cells was inhibited by nitrendipine, D-600, and diltiazem ( IC $_{50}$ values $=7,690$, and $1600 \mathrm{nM}$ ). Our results suggest that VSCCs in neuronal clonal cell lines can be altered by cellular differentiation. In contrast to those VSCCs involved in neurotransmitter release, the VSCCs described here appear to be blocked by organic calcium channel antagonists at very low concentrations.
\end{abstract}

Calcium ions play an important role in the control of cellular function in all tissues. An important feature of this regulation is that the intracellular free calcium ion concentration is kept within low (nanomolar) concentrations compared with the millimolar concentrations present extracellularly. The entry of calcium ions into the cell is rigidly controlled. Calcium influx through voltagesensitive calcium channels (VSCCs) represents one of the major mechanisms for the regulation of calcium entry, particularly in neurons and some muscle and endocrine cells. The entry of calcium through VSCCs is important for initiating contraction of smooth and cardiac muscle, and also for release of neurotransmitters and hormones from neuronal and endocrine cells.

\footnotetext{
${ }^{1}$ This work was supported by United States Public Health Service Grants PHS DA-02121 and PHS DA-02575. S. B. F. is a North Atlantic Treaty Organization (United Kingdom) Fellow. R. J. M. is an Alfred P. Sloan Fellow. We thank S. Kongsamut and T. Grady for assistance with these studies.

${ }^{2}$ To whom correspondence should be addressed.
}

A variety of organic compounds, such as verapamil and nifedipine, have been shown to block VSCCs in muscle (Fleckenstein, 1977; Triggle, 1981). These substances are now widely used in the treatment of certain cardiovascular disorders, such as angina, cardiac arrhythmias, and hypertension (Henry, 1980).

There is considerable evidence that organic calcium blockers block VSCCs in smooth muscle. For example, they block excitation-contraction coupling (Flaim, 1982) and slow inward calcium currents (Ehara and Kaufmann, 1978) and depolarization-induced ${ }^{45} \mathrm{Ca}^{2+}$ influxes (Triggle, 1981; Weiss, 1982). These same drugs exhibit a lower affinity for VSCCs in the heart (Lee and Tsien, 1983). Moreover, neuronal calcium currents, as measured electrophysiologically, are extremely insensitive to organic calcium channel blockers (Baker et al., 1973; Kostyuk and Krishtal, 1977; Moolenaar and Spectro, 1979; Llinas and Sugimori, 1980). In addition, Blaustein and colleagues (Nachshen and Blaustein, 1979) have found that the depolarization-induced influx of ${ }^{45} \mathrm{Ca}^{2+}$ into synaptosomes is completely insensitive to dihydropyridines 
such as nifedipine and is only blocked by very high nonspecific concentrations of verapamil and D-600. Control of the influx of calcium required for neurotransmitter release from nerve terminals represents one of the most important functions of VSCCs in nerve, yet this excitation/secretion coupling is completely insensitive to high concentrations of nifedipine and is only blocked by enormous concentrations of verapamil (Haeusler, 1972; Starke and Schümann, 1973; Van der Kloot and Kita, 1975; Högestätt et al., 1982) that also block voltagesensitive sodium channels (Baker et al., 1973; Galper and Catterall, 1979; Nachshen and Blaustein, 1979), neurotransmitter uptake (McGee and Schneider, 1979), receptor-ligand interactions (Karliner et al., 1982; Quirion and Pert, 1982), and a host of other cellular parameters.

Identification of VSCCs at the biochemical level has recently become possible with the preparation of radioactive derivatives of the dihydropyridine calcium antagonists, ${ }^{3} \mathrm{H}$-nitrendipine and ${ }^{3} \mathrm{H}$-nimodipine. In smooth (Bolger et al., 1982; Ehlert et al., 1982), cardiac (Bellemann et al., 1981; Bolger et al., 1982; Ehlert, et al., 1982), and skeletal muscle (Fairhurst et al., 1983; Fosset et al., 1983), and in brain (Gould et al., 1982; Ehlert et al., 1982; Marangos et al., 1982), several laboratories have been able to demonstrate a high affinity binding site for these drugs. In smooth muscle, affinities of organic calcium blockers for these binding sites correlate fairly well with their ability to inhibit excitation/contraction coupling and calcium influx (Bolger et al., 1982). This suggests that these binding sites represents VSCCs in smooth muscle. A similar binding site has been identified in brain despite the apparent lack of pharmacological effects of these drugs in neuronal tissue. It is an important goal to try to establish whether ${ }^{3} \mathrm{H}$-nitrendipine binding sites in nerve really correspond to VSCCs. In order to examine further the behavior of organic calcium channel blockers in neuronal tissue, we have investigated a number of neuronal clonal cell lines for the presence and pharmacological sensitivity of voltage-sensitive calcium channels. Clonal cells in culture represent a useful system for studying ion channels and receptors in a homogeneous cell system where biochemical, physiological, and electrophysiological measurements can be correlated. We report the presence of VSCCs in a variety of neuronal cell lines which are blocked by low concentrations of organic calcium antagonists.

\section{Materials and Methods}

Clonal cell lines. A variety of neuronal cell lines have been examined for voltage-sensitive ${ }^{45} \mathrm{Ca}^{2+}$ uptake, including the neuroblastoma N4TG1, the neuroblastoma $\times$ glioma hybrid NG108-15, and the neuroblastoma $\times$ Chinese hamster brain explant hybrid NCB-20 (gifts of Dr. A. Gilman, University of Virginia, Dr. W. Klee, National Institutes of Health, Bethesda, MD, and Dr. J. Minna, Veterans Administration Hospital, Washington, D. C., respectively). Cells were grown as monolayers under $5 \% \mathrm{CO}_{2}$ in Eagle's minimal essential medium (EMEM) supplemented with $10 \%$ fetal bovine serum and $2 \mathrm{mM}$ glutamine.

${ }^{45} \mathrm{Ca}^{2+}$ uptake studies. Cells (passage 5-20) were sub- cultured onto $60-\mathrm{mm}$ tissue culture plates and allowed to grow for 4 to 6 days. During the assay, tissue culture plates were supported in an open air waterbath at $37^{\circ} \mathrm{C}$. Cells were preincubated for $5 \mathrm{~min}$ at $37^{\circ} \mathrm{C}$. The uptake of ${ }^{45} \mathrm{Ca}^{2+}$ was measured for increasing periods of time in HEPES (20 mM)-buffered EMEM containing $135.7 \mathrm{mM}$ $\mathrm{NaCl}, 5 \mathrm{mM} \mathrm{KCl}, 0.44 \mathrm{mM} \mathrm{KH}_{2} \mathrm{PO}_{4}, 0.34 \mathrm{mM} \mathrm{Na}_{2} \mathrm{HPO}_{4}$, $2.62 \mathrm{mM} \mathrm{NaHCO}_{3}, 1.3 \mathrm{~mm} \mathrm{CaCl}, 0.81 \mathrm{~mm} \mathrm{MgSO}_{4}$, and $5.6 \mathrm{~mm}$ glucose. $\mathrm{KCl}$ buffer $(50 \mathrm{~mm})$ was prepared by adjusting $\mathrm{Na}^{+}$reciprocally. ${ }^{45} \mathrm{Ca}^{2+}$ was added to give a final concentration of $1 \mu \mathrm{Ci} / \mathrm{ml}$ of ${ }^{45} \mathrm{Ca}^{2+}$. At the indicated times, plates were aspirated, washed immediately, and inverted to allow them to dry. Cells were solubilized with $5 \mathrm{ml}$ of $0.2 \%$ SDS and samples were removed for estimation of ${ }^{45} \mathrm{Ca}^{2+}$ uptake and protein content by fluorescence (Avrach and Wallach, 1971).

Cellular differentiation. Cells were subcultured onto $60-\mathrm{mm}$ tissue culture plates and allowed to grow for 3 days. To induce cellular differentiation, growth medium was supplemented with $10 \mu \mathrm{M}$ prostaglandin $\mathrm{E}_{1}$ and 50 $\mu \mathrm{M}$ 3-isobutyl-l-methylxanthine (IBMX). In parallel experiments, other workers in our laboratory have shown that this treatment will increase intracellular cAMP levels by 10- to 100-fold (E. Berry-Kravis, personal communication). Cells were examined visually for morphological differentiation and were assayed for net ${ }^{45} \mathrm{Ca}^{2+}$ uptake at varying time points following treatment. Supplemented medium was replaced every 2 days or when required. Control cells were grown under identical conditions with an equivalent volume of ethanol added per culture plate.

Materials. ${ }^{45} \mathrm{Ca}^{2+}$ (10 to $40 \mathrm{mCi} / \mathrm{mg}$ of calcium) was obtained from Amersham Corp., (Arlington Heights, IL). The following compounds were generous gifts: nitrendipine, nisoldipine, and minodipine (Miles Laboratories Inc.); flunarizine, cinnarizine, and lidoflazine (Janssen Pharmaceutics Inc.), D-600 and D-890 (Knoll AG, Germany), diltiazem (Marion Laboratories, Inc.), bepridil (McNeil Pharmaceuticals), nifedipine (Pfizer Pharmaceutical), prenylamine (Hoechst-Roussel Pharmaceuticals Inc.), pirmenol (Warner Lambert), Glaxo CCl 22277 (Glaxo, U. K.), ryanodine (Merck, Sharp and Dohme), optical isomers of nimodipine (Bayer AG, Germany), and optical isomers of verapamil (Dr. R. Karl, University of Chicago). Dr. R. Gould (Johns Hopkins University, Baltimore, MD) kindly supplied felodipine, the isomers of diltiazem and Tiapamil. Dr. Rahwan (Ohio State University, Columbus, $\mathrm{OH}$ ) and Dr. Thomae (A Biologische forshung, Biberach/Riss, West Germany) provided prMDI and AQA-39, respectively. Batrachotoxin was a very kind gift of Dr. J. Daly, (National Institutes of Health, Washington, D. C.). Scorpion venom (Leiurus quinquestriatus) was purchased from Sigma Chemical Co., St. Louis, MO). Dr. W. Trautwein (Universitat der Saarlandes, Homburg, Germany) kindly provided an additional supply of D-890. All other drugs used in this study were purchased from commercial sources.

\section{Results}

${ }^{45} \mathrm{Ca}^{2+}$ uptake into neuroblastoma cells. Depolarization of NCB-20 cells by increasing the potassium concentration of the incubation buffer from $5 \mathrm{~mm}$ to $50 \mathrm{~mm}$ 
produced a large increase in the uptake of ${ }^{4 .} \mathrm{Ca}^{2+}$. Over a 10-min period, the depolarized cells had accumulated $3.02 \pm 0.06 \mathrm{nmol}$ of calcium $/ \mathrm{mg}$ of protein compared with $0.97 \pm 0.03 \mathrm{nmol} / \mathrm{mg}$ of protein for control $(5 \mathrm{mM}$ $\mathrm{KCl}$ ) incubations (Fig. $1 A$ ). The depolarization-sensitive uptake was relatively rapid, with half-maximal accumulation occurring within $5 \mathrm{~min}$ at $37^{\circ} \mathrm{C}$. The initial rate of ${ }^{45} \mathrm{Ca}^{2+}$ uptake in $50 \mathrm{mM} \mathrm{KCl}$ was approximately 3 times that seen in low $\mathrm{K}^{+}(5 \mathrm{~mm})$ buffer. In contrast, uptake in low $\mathrm{K}^{+}$appeared to be linear over the duration of the experiments. Following $10 \mathrm{~min}$ of incubation, the rate of ${ }^{45} \mathrm{Ca}^{2+}$ uptake by depolarized cells was similar to that in control cells. Incubations allowed to continue for $5 \mathrm{hr}$ showed no difference in ${ }^{45} \mathrm{Ca}^{2+}$ content betwen control cells and cells incubated in depolarizing concentrations of $\mathrm{K}^{+}$, suggesting that the depolarization-sensitive uptake was due to a change in the rate of uptake rather than a change in compartment size. Increasing the potassium concentration from $50 \mathrm{mM}$ to $120 \mathrm{mM} \mathrm{KCl}$ did not further stimulate ${ }^{4.5} \mathrm{Ca}^{2+}$ uptake.

In contrast to NCB-20 cells, only a small depolarization-sensitive uptake was seen with N4TG1 cells ( $1.43 \pm$ $0.03 \mathrm{nmol} / \mathrm{mg}$ of protein $/ 10 \mathrm{~min}$, normal $\mathrm{K}^{+} ; 2.02 \pm 0.15$ $\mathrm{nmol} / \mathrm{mg}$ of protein $/ 10 \mathrm{~min}$, high $\left.\mathrm{K}^{+}, n=4\right)($ Fig. $1 B$ ).
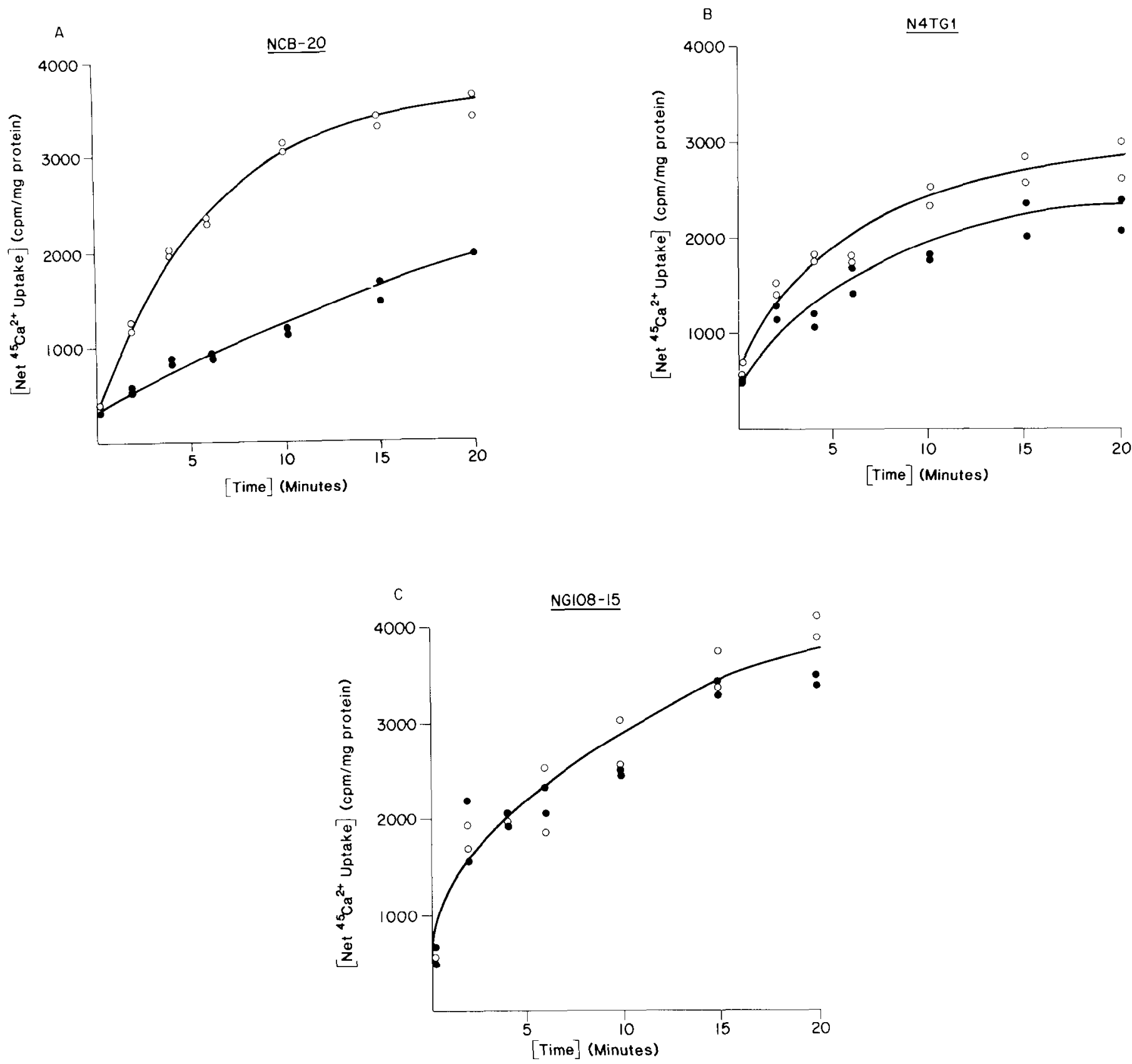

Figure 1. Time course of ${ }^{4.5} \mathrm{Ca}^{2+}$ uptake in low $\mathrm{K}^{+}(5 \mathrm{mM})(0)$ and high $\mathrm{K}^{1}(50 \mathrm{~mm})(\mathrm{O})$ buffer. Cells were washed and ${ }^{45} \mathrm{Ca}{ }^{2+}$ uptake was determined as described under "Materials and Methods." Zero time points of ${ }^{45} \mathrm{Ca}^{2+}$ uptake have been included with the data presented. Each point represents single experimental observations performed in duplicate. Each curve is a typical experimental result that has been obtained on at least four separate occasions. $A$, NCB-20 cells; $B$, N4TG1 cells; $C$, NG108-15 cells. 
Little or no increase was seen with NG108-15 cells (1.96 $\pm 0.1 \mathrm{nmol} / \mathrm{mg}$ of protein $/ 10 \mathrm{~min}$, normal $\mathrm{K}^{+} ; 2.32 \pm$ $0.26 \mathrm{nmol} / \mathrm{mg}$ of protein $/ 10 \mathrm{~min}$, high $\mathrm{K}^{+}, n=4$ ) (Fig. $1 C)$. Over several experiments, we observed that the response in NG108-15 cells was somewhat variable. In view of our findings with agents that differentiate cells (see below), it is possible that this reflected differences in the degree of differentiation within cultures. However, the response in NG108-15 cells, even when present, was generally much smaller than that seen in NCB-20 cells.

We have also studied the possible inactivation of the voltage-sensitive ${ }^{45} \mathrm{Ca}^{2+}$ uptake in NCB-20 cells. Cells were depolarized with $50 \mathrm{mM} \mathrm{K}{ }^{+}$for varying lengths of time before the addition of ${ }^{45} \mathrm{Ca}^{2+}$. It can be seen (Fig. 2) that there was a $49 \%$ reduction in the initial rate of ${ }^{45} \mathrm{Ca}^{2+}$ uptake following $2 \mathrm{~min}$ of prior depolarization. Little further reduction was seen during a 10-min predepolarization. This would suggest that at least some of the VSCCs present do inactivate within $2 \mathrm{~min}$, whereas a second population inactivates more slowly if at all.

Effect of organic calcium channel antagonists. The depolarization-sensitive uptake of ${ }^{15} \mathrm{Ca}^{2+}$ into NCB-20 cells was inhibited by a wide variety of drugs which have been shown to block voltage-sensitive calcium channels in muscle (Table I). In particular, dihydropyridine derivatives such as nifedipine, nisoldipine, and nitrendipine were particularly potent, exerting their effects at nanomolar concentrations. Phenylalkylamines and diphenylalkylamines, such as D-600 and cinnarizine, were at least two orders of magnitude less potent. Another clinically used calcium antagonist, the benzothiazepine derivative diltiazem, was also less potent with an $\mathrm{IC}_{50}$ value of $4.5 \mu \mathrm{M}$.

As can be seen from Figure 3, the inhibition curves of these drugs were parallel to each other and had slopes close to unity. This implies that these drugs may have a similar mechanism of action at calcium channels in these cells.

Several of the drugs utilized in this study were shown to block in a stereospecific manner. In Table II, it can be seen that with both nimodipine and verapamil, calcium channel blocking activity resides primarily with the $(-)$-enantiomer. Similarly, studies have shown that des-

\section{TABLE I}

Inhibition of voltage-sensitive ${ }^{45} \mathrm{Ca}^{2+}$ uptake into $\mathrm{NCB}-20$ cells

The depolarization-sensitive uptake was inhibited by a wide variety of organic calcium channel antagonists. Assays were performed as described in the legend to Figure 1 and under "Materials and Methods." Drugs were preincubated with the cells for $5 \mathrm{~min}$ before addition of the high $\mathrm{K}^{+}(50 \mathrm{mM} \mathrm{KCl})$ buffer and were present throughout the $10-\mathrm{min}$ incubation in the presence of $1 \mu \mathrm{Ci} / \mathrm{ml}$ of ${ }^{45} \mathrm{Ca}^{2+}$. The organic calcium channel antagonists had no effect on low $\mathrm{K}^{+}(5 \mathrm{~mm} \mathrm{KCl})$ basal uptake. Each curve consisted of at least four separate concentrations of drug, performed as quadruplicate determinations. Each curve was determined on at least three separate occasions. $\mathrm{IC}_{50}$ is the concentration of drug required to inhibit the depolarization-sensitive component of ${ }^{45} \mathrm{Ca}^{2+}$ uptake by $50 \%$.

\begin{tabular}{lr}
\hline \multicolumn{1}{c}{ Drug } & IC $_{50}(\mathrm{nM})$ \\
\hline Nisoldipine & 0.58 \\
Felodipine & 2.10 \\
Nimodipine & 5.60 \\
Nitrendipine & 6.40 \\
Nifedipine & 9.20 \\
D-600 & 350.00 \\
Flunarizine & 750.00 \\
Cinnarizine & 750.00 \\
Lidoflazine & 800.00 \\
Prenylamine & 1500.00 \\
Bepridil & 1600.00 \\
Verapamil & 1800.00 \\
Diltiazem & 4500.00 \\
Trifluoperazine & Inactive $^{a}$ \\
Tetrodotoxin & Inactive $^{a}$ \\
Apamin & Inactive $^{b}$ \\
TEA & Inactive $^{b}$ \\
4-Aminopyri- & Inactive $^{b}$ \\
dine & \\
\hline
\end{tabular}

${ }^{a}$ At concentrations $\leq 10 \mu \mathrm{M}$.

${ }^{b}$ At concentrations $\leq 1 \mathrm{mM}$.

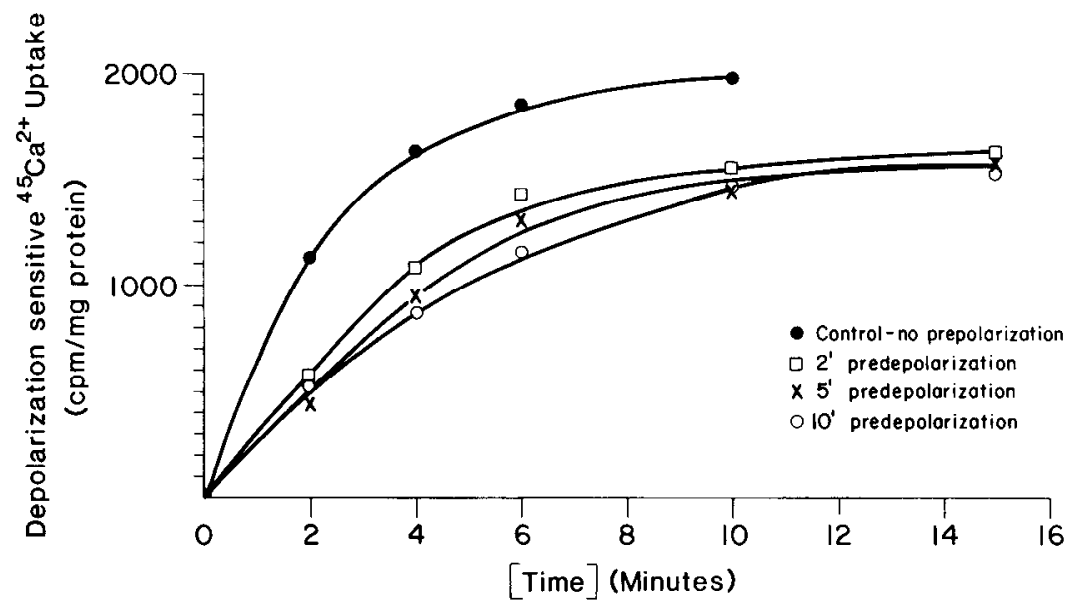

Figure 2. Effect of increasing preincubation time of NCB-20 cells in high $\mathrm{K}^{+}(50 \mathrm{mM} \mathrm{KCl})$ medium on subsequent ${ }^{45} \mathrm{Ca}^{2+}$ uptake. Net ${ }^{45} \mathrm{Ca}^{2+}$ uptake was measured for varying lengths of time in either low $\mathrm{K}^{+}(5 \mathrm{mM} \mathrm{KCl})$ or high $\mathrm{K}^{+}(50 \mathrm{mM} \mathrm{KCl}) \mathrm{media}$ containing $1.0 \mu \mathrm{Ci} / \mathrm{ml}$ of ${ }^{45} \mathrm{Ca}^{2+}$. Prior to this measurement, cells were preincubated in $50 \mathrm{mM} \mathrm{KCl}$-containing medium for the times indicated. Each data point is the mean of triplicate determinations. Initial rates of uptake were determined graphically from the initial linear portion of the curve. 0 , no preincubation; $\square, 2$ min preincubation; $X, 5$ min preincubation; $O$, 10 min preincubation. Low $\mathrm{K}^{+}(5 \mathrm{mM} \mathrm{KCl})$ uptake curves were performed in parallel and have been subtracted from the results presented. 
methyl-cis-diltiazem is less potent as a calcium channel blocker than cis/trans diltiazem, whereas trans-diltiazem is completely inactive (Table II). These results indicate that both the stereoselective and the structural requirements for organic calcium channel blockers acting upon VSCCs in NCB-20 cells are similar to those for their actions on VSCCs in other tissues (Jim et al., 1981; Towart et al., 1982; Murphy et al., 1983).

In recent years, a number of novel compounds with a variety of chemical structures have been developed and tested as potential antagonists of VSCCs. We have examined a number of these compounds as potential blockers of depolarization-induced calcium uptake into NCB20 cells (see Table 3 ). In this group, the steroidal antagonist Glaxo CCI 22277 (Campbell and Vaughan Williams, 1982) and ruthenium red (Swanson et al., 1975) were reasonably potent antagonists. In contrast, Pirmenol (Mertz and Kaplan, 1982) and AQA-39 (Trautwein et al., 1981) were inactive at concentrations below $10 \mu \mathrm{M}$. TMB-8 (Malagodi and Chiou, 1974) and prMDI (Lynch and Rahwan, 1982) are two compounds that have been suggested to antagonize intracellular calcium mobilization preferentially. In the present study, prMDI was completely inactive, whereas TMB-8 was able to inhibit voltage-sensitive ${ }^{45} \mathrm{Ca}^{2+}$ influx, at relatively high concentrations. D-890 is a quaternary ammonium derivative of D600 which is presumed not to be able to cross cellular membranes (Hescheler et al., 1982). This compound is reported not to block VSCCs in muscle measured electrophysiologically unless it is applied intracellularly. D 890 was a very weak blocker of depolarization

\section{TABLE II}

Stereoisomerism of calcium channel antagonism in NCB-20 cells

The depolarization-sensitive uptake was stereospecifically inhibited by a variety of organic calcium channel antagonists. $\mathrm{IC}_{50}$ values were determined as previously described.

\begin{tabular}{lc}
\multicolumn{1}{c}{ Drug } & $\begin{array}{c}\mathrm{IC}_{50} \text { Value } \\
(\mathrm{nM})\end{array}$ \\
\hline$(-)$-Nimodipine & 7.0 \\
$(+)$-Nimodipine & 68.0 \\
$(-)$-Verapamil & 900.00 \\
$(+)$-Verapamil & 3600.00 \\
cis/trans-Diltiazem & 4500.00 \\
Desmethyl-cis-Diltiazem & 6400.00 \\
trans-Diltiazem & Inactive $^{a}$ \\
\hline
\end{tabular}

${ }^{a}$ At concentrations $\leq 10 \mu \mathrm{M}$.

TABLE III

Effects of novel agents upon depolarization-sensitive ${ }^{45} \mathrm{Ca}^{2+}$ uplake inlo NCB-20 cells

\begin{tabular}{lc}
\hline \multicolumn{1}{c}{ Drug } & $\mathrm{IC}_{50}$ Value $(\mu \mathrm{M})^{a}$ \\
\hline Glaxo CCl 22277 & 1.0 \\
Ruthenium red & 1.3 \\
Ryanodine & 2.7 \\
TMB-8 & 15 \\
D890 & $30^{b}$ \\
Pirmenol & Inactive $^{c}$ \\
AQA-39 & Inactive $^{c}$ \\
prMDI & Inactive $^{c}$ \\
\hline
\end{tabular}

${ }^{a} \mathrm{IC}_{50}$ values were determined as described previously.

${ }^{b}$ This compound only gave $50 \%$ inhibition at the highest concentration used $(30 \mu \mathrm{M})$.

' These compounds were inactive at concentrations $\leq 10 \mu \mathrm{M}$. sensitive calcium uptake into NCB-20 cells when applied to the external bathing solution. According to the argument of Hescheler and colleagues this would imply that the active site for the action of D600 and verapamil is on the inside of the cell membrane. However, in other studies, we have also observed that D-890 at concentrations below $10 \mu \mathrm{M}$ does not block the binding of ${ }^{3} \mathrm{H}$ nitrendipine to brain membranes, whereas both $\mathrm{D}-600$ and verapamil do so (unpublished observation).

In electrophysiological studies, blockade of VSCCs by organic calcium channel antagonists can be reversed, at least partially, by increasing the extracellular calcium ion concentration (Hagiwara and Byerly, 1981; Lee and Tsien, 1983). The VSCCs identified in the present study appear to share this characteristic (Table IV). Interestingly, this feature appears to occur for all major classes of calcium channel antagonists.

None of the organic calcium channel antagonists had any effect upon basal (low $\mathrm{K}^{+}$) net calcium uptake, except at very high concentrations. The specificity of the blockade was also demonstrated by the absence of blocking by tetrodotoxin (TTX) (3 $\mu \mathrm{M})$, a sodium channel blocker, and 4-aminopyridine, tetraethylammonium (TEA), and

TABLE IV

Effect of extracellular calcium ion concentration upon blockade of voltage-sensitive calcium channels by a variety of organic antagonists

\begin{tabular}{lcc}
\hline \multirow{2}{*}{ Drug $^{a}$} & \multicolumn{2}{c}{ External Calcium Concentration } \\
\cline { 2 - 3 } & $1.3 \mathrm{mM}$ & $5.0 \mathrm{mM}$ \\
\hline & $\mathrm{IC}_{50}(\mathrm{nM})$ & $\mathrm{IC}_{50}(\mathrm{nM})$ \\
Nitrendipine & 12.0 & 25.0 \\
D-600 & 760.00 & 1700.00 \\
Cinnarizine & 1600.00 & Inactive $^{b}$ \\
Diltiazem & 2000.00 & Inactive $^{c}$ \\
\hline
\end{tabular}

${ }^{a}$ In contrast to the previously described experiments, the drugs in this study were not preincubated with the cells prior to the uptake assay.

${ }^{b}$ Twenty-eight percent displacement at $30 \mu \mathrm{M}$. Solubility problems occurred at higher concentrations.

${ }^{c}$ Inactive at concentrations $\leq 3.0 \mu \mathrm{M}$.

TABLE V

Effect of divalent cations upon depolarization-sensitive ${ }^{45} \mathrm{Ca}^{2+}$ uptake into NCB-20 cells

$\mathrm{IC}_{50}$ is the concentration of metal cation required to inhibit the depolarization-sensitive ${ }^{45} \mathrm{Ca}^{2+}$ uptake by $50 \%$. Divalent ions were added to the high $\mathrm{K}^{+}(50 \mathrm{~mm} \mathrm{KCl})$ buffer at the start of the incubation period. The cations (at $1 \mathrm{~mm}$ ) all inhibited low $\mathrm{K}^{+}(5 \mathrm{mM} \mathrm{KCl})$ basal uptake by 20 to $25 \%$. Each value was calculated from quadruplicate determinations performed on at least three separate occasions.

Inhibitory Effects of Cations at $1 \mathrm{~mm}$

$\begin{array}{lc}\text { Divalent Cation } & \begin{array}{c}\text { Inhibition of Depolarization- } \\ \text { sensitive }\end{array} \\ 1 \mathrm{mM} \mathrm{CdCl}_{2} \mathrm{Ca}^{2+} \text { Uptake }\end{array}$

$\mathrm{IC}_{50}$ Values for Various Cations

$\begin{array}{lc}\text { Divalent Cation } & \mathrm{IC}_{50} \text { Value }(\mu \mathrm{M}) \\ \text { Cadmium } & 56 \\ \text { Manganese } & 270 \\ \text { Cobalt } & 660 \\ \text { Strontium } & 8000\end{array}$




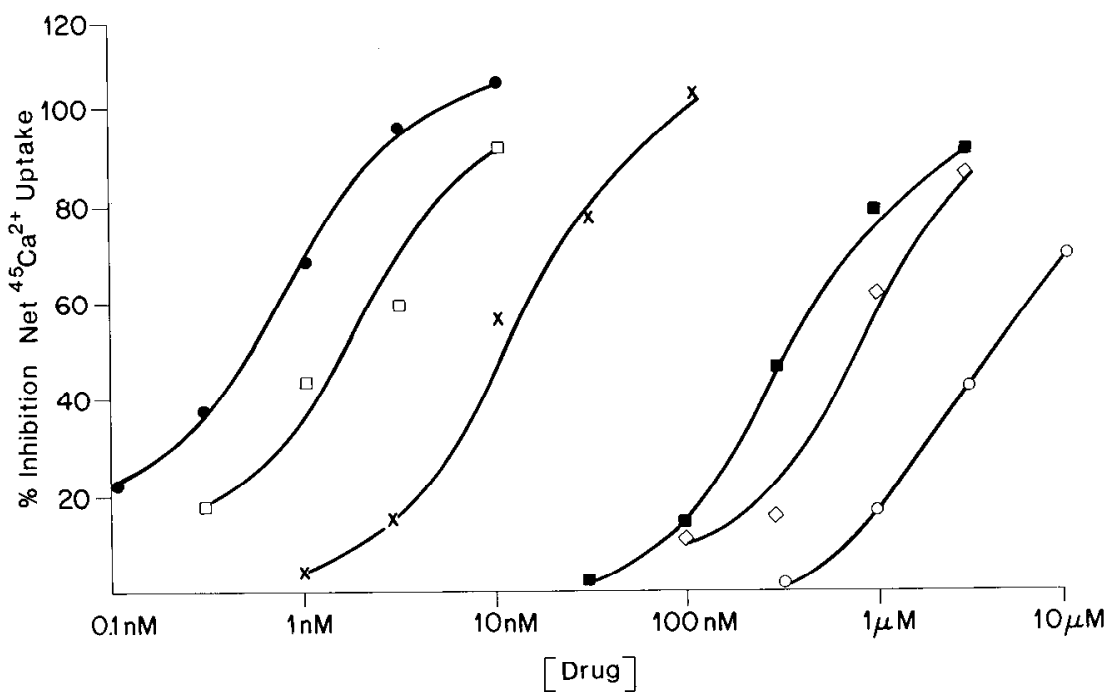

Figure 3. Effects of organic calcium channel blockers on high $\mathrm{K}^{+}$-stimulated ${ }^{45} \mathrm{Ca}^{2+}$ uptake. $\mathrm{NCB}-20$ cells were preincubated for $5 \mathrm{~min}$ at $37^{\circ} \mathrm{C}$ in the presence of the indicated concentrations of drugs. Depolarization-sensitive uptake was measured as the difference in ${ }^{45} \mathrm{Ca}^{2+}$ uptake over $10 \mathrm{~min}$ in HEPES-buffered EMEM containing either 5 or $50 \mathrm{mM} \mathrm{KCl}$. Protocol was similar to that described under "Materials and Methods" and in the legend to Figure 1. Each point is the mean of quadruplicate determinations performed on at least three separate occasions. Standard errors have been omitted for clarity, but they were typically less than $5 \%$. $\bullet$, nisoldipine; $\square$, felodipine; $X$, nifedipine; $\mathbf{0}, \mathrm{D}-600 ; \diamond$, cinnarizine; $O$, diltiazem.

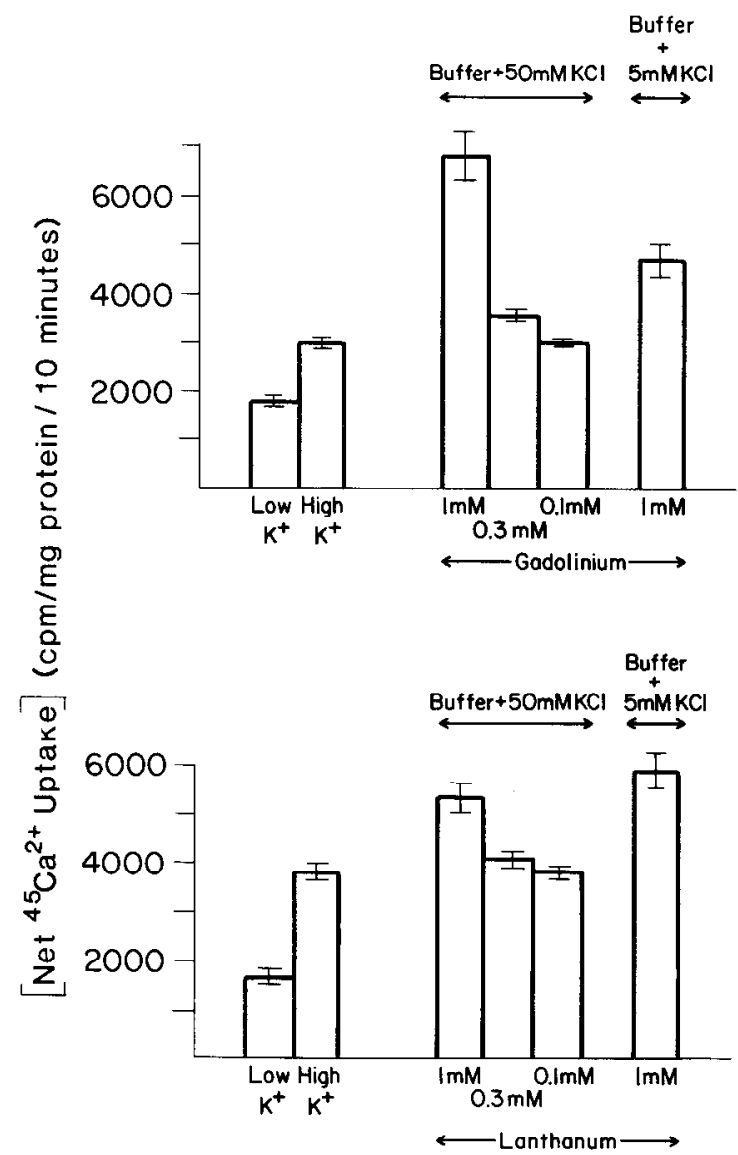

Figure 4. Effects of trivalent cations upon depolarizationsensitive and control ${ }^{45} \mathrm{Ca}^{2+}$ uptake. Trivalent cations were added to the cells at the start of the incubation period in the presence of either low $\mathrm{K}^{+}(5 \mathrm{mM} \mathrm{KCl})$ or high $\mathrm{K}^{+}(50 \mathrm{mM} \mathrm{KCl})$ buffer. Protocol was similar to that previously described. Results are expressed as net ${ }^{45} \mathrm{Ca}^{2+}$ uptake into the cells during a 10-min incubation period. Values correspond to low or high high $\mathrm{K}^{+}$buffer as indicated. Results are mean \pm SEM of quadruplicate determinations performed on at least two separate occasions. apamin (blockers of a variety of potassium channels) at concentrations up to $1 \mathrm{mM}$. Trifluoperazine is a phenothiazine neuroleptic which has been shown to inhibit calmodulin in a variety of tissues (Connor et al., 1982). In the present study, trifluoperazine inhibited depolarization-sensitive ${ }^{45} \mathrm{Ca}^{2+}$ uptake only at concentrations of $10 \mu \mathrm{M}$ or above. However, this effect may be nonspecific since at these concentrations, both low $\mathrm{K}^{+}$(control) uptake and cell viability were diminished.

Blockade of uptake by divalent metal cations. Calcium uptake was also blocked by a variety of divalent metal cations (see Table V), with cadmium being the most potent. The rank order of potency for these cations $(\mathrm{Cd}$ $>\mathrm{Ni}>\mathrm{Mn}>\mathrm{Co}$ ) and their ability to block in the micromolar concentration range is in agreement with a number of electrophysiological studies (Hagiwara and Byerly, 1981). Strontium had only moderate activity in this assay. Indeed, rather than blocking VSCCs, strontium and barium have been shown by other workers to be able to carry current through VSCCs (Hagiwara and Byerly, 1981). In contrast to organic calcium channel antagonists which had no effect on basal ${ }^{45} \mathrm{Ca}^{2+}$ uptake, all of the divalent cations inhibited basal ${ }^{45} \mathrm{Ca}^{2+}$ uptake by approximately $25 \%$ at a concentration of $1 \mathrm{~mm}$.

Lanthanum and gadolinium are two trivalent metal cations that have been shown to have complex effects on VSCCs. Thus, $\mathrm{La}^{3+}$ can block the evoked release of neurotransmitter. In addition, $\mathrm{La}^{3+}$ can strongly stimulate the release of transmitter when added in the absence of depolarization (Heuser and Miledi, 1971). $\mathrm{La}^{3+}$ also blocks other calcium-related cellular functions such as the $\mathrm{Na}^{+} / \mathrm{Ca}^{2+}$ exchange present in many cells. In Figure 4 , it can be seen that both trivalent metal cations produced a small stimulation of both the depolarizationsensitive component and the control basal component of ${ }^{45} \mathrm{Ca}^{2+}$ uplake. It seems likely that the VSCC blocking effects of these ions are masked in these studies by other effects. 
Other mechanisms for ${ }^{45} \mathrm{Ca}^{2+}$ entry. It has been shown previously by other workers that calcium entry into cells may be regulated by a variety of mechanisms besides VSCCs. Two such important mechanisms are $\mathrm{Na}^{+} / \mathrm{Ca}^{2+}$ exchange (Erdreich et al., 1983) and voltage-sensitive $\mathrm{Na}^{+}$channels (Jacques et al., 1981). In the present study, it was important to distinguish these processes from direct entry of ${ }^{45} \mathrm{Ca}^{2+}$ through VSCCs.

Depolarization-induced ${ }^{45} \mathrm{Ca}^{2+}$ uptake was not dependent upon extracellular $\mathrm{Na}^{+}$since, in Figure 5, it can be seen that a depolarization-sensitive component was still evident when extracellular $\mathrm{Na}^{+}$was replaced by choline. The absolute levels of ${ }^{45} \mathrm{Ca}^{2+}$ within the cell tended to be slightly increased when cells were incubated in the absence of $\mathrm{Na}^{+}$. This may reflect an extrusion system, whereby a small amount of $\mathrm{Ca}^{2+}$ is normally pumped out of the cell in exchange for extracellular $\mathrm{Na}^{+}$.

Voltage-sensitive $\mathrm{Na}^{+}$channels have been identified in a variety of nerve cell lines (Catterall, 1975; Stallcup, 1979). Veratridine is an alkaloid neurotoxin which has been shown to stimulate ${ }^{22} \mathrm{Na}^{+}$fluxes through these channels in neuroblastoma cells (Catterall, 1975). $\mathrm{Na}^{+}$ channels are normally only open for short periods of time but can be shown to be persistently activated in the presence of veratridine (Hille, 1968). In the present study, ${ }^{45} \mathrm{Ca}^{2+}$ uptake was stimulated by $10 \mu \mathrm{M}$ veratridine
(Fig. 6), producing a net uptake that was $72 \%$ of that achieved by $50 \mathrm{mM} \mathrm{K}{ }^{+}$. Increasing the concentration of veratridine from $10 \mu \mathrm{M}$ to $50 \mu \mathrm{M}$ produced a response equivalent to that produced by $50 \mathrm{mM} \mathrm{K}^{+}$(Fig. 7). The maximum responses to veratridine and high $\mathrm{K}^{+}$were not additive. In contrast to high $\mathrm{K}^{+}$stimulation, alkaloidstimulated ${ }^{45} \mathrm{Ca}^{2+}$ uptake was dependent on extracellular sodium ions and was blocked by TTX (Fig. 7), in a concentration-dependent manner $\left(\mathrm{IC}_{50}=25 \mathrm{nM}\right)$.

Two other toxins which have been shown to interact with sodium channels are batrachotoxin (Catterall, 1980), which acts in a manner similar to veratridine, and scorpion venom. The latter substance enhances persistent activation produced by veratridine and batrachotoxin. Batrachotoxin stimulated ${ }^{45} \mathrm{Ca}^{2+}$ uptake in a concentration-dependent manner (Fig. 8); its $\mathrm{EC}_{50}$ value was $700 \mathrm{nM}$. Interestingly, scorpion venom at $100 \mathrm{ng} / \mathrm{ml}$, a dose which had no effect on ${ }^{45} \mathrm{Ca}^{2+}$ uptake, produced a potentiation of the response to batrachotoxin (Fig. 8). As with veratridine, the response to batrachotoxin was not additive with that produced by $50 \mathrm{mM} \mathrm{K}{ }^{+}$.

It has recently been suggested that batrachtoxin can selectively block voltage-sensitive calcium channels in nerve in addition to its effects on sodium channels (Romey and Lazdunski, 1982). To test this hypothesis, we have investigated the effects of batrachotoxin during 50
A

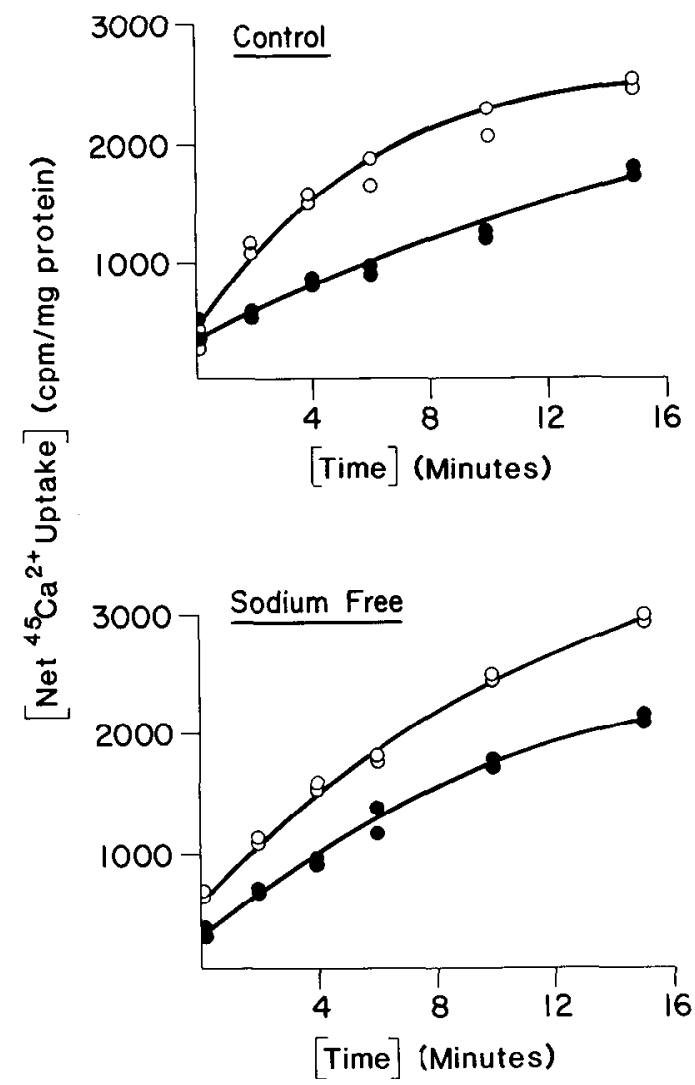

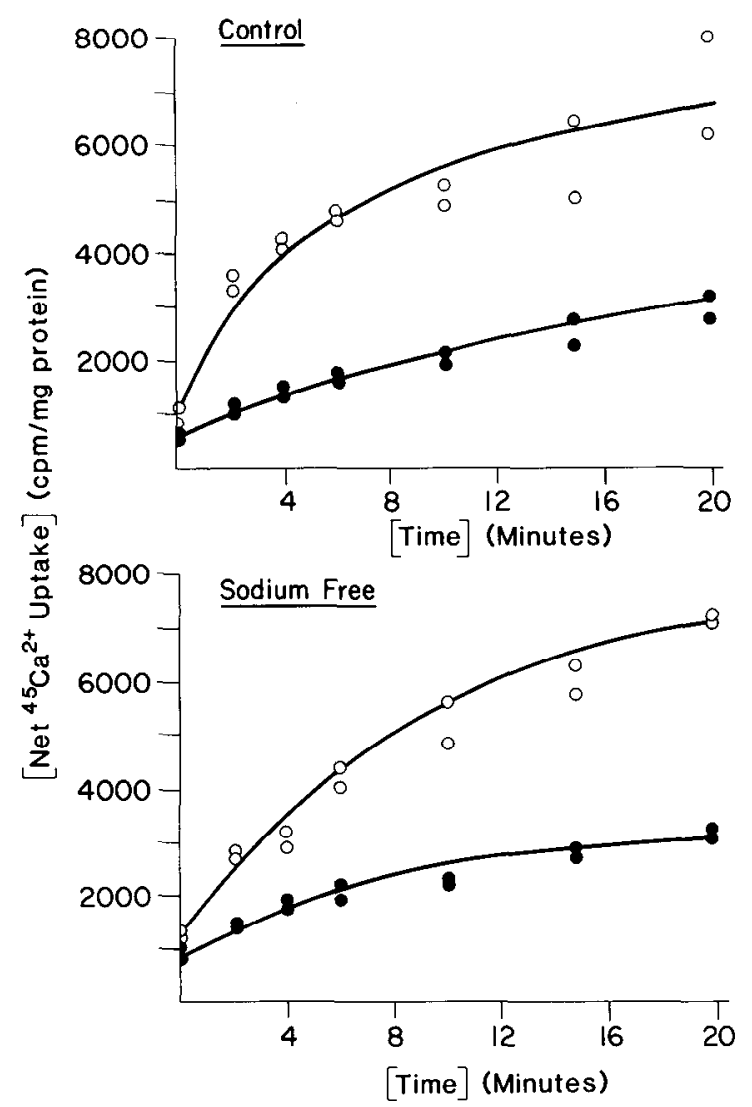

Figure 5. Role of sodium ions upon depolarization-sensitive ${ }^{45} \mathrm{Ca}^{2+}$ uptake into NCB-20 cells $(A)$ and differentiated NG108-15 cells $(B)$. Uptake of ${ }^{45} \mathrm{Ca}^{2+}$ was measured in sodium-free, choline chloride-substituted HEPES-Krebs solution. The choline ${ }^{+}$was adjusted so that choline ${ }^{+}+\mathrm{K}^{+}=140 \mathrm{mM}$. NG108-15 cells were differentiated for 4 days with $10 \mu \mathrm{M}$ PGE 1 and $50 \mu \mathrm{M}$ IBMX (see under "Results," "Effect of differentiation upon VSCCs"). Results are expressed as duplicate determinations and are representative experiments performed on at least two separate occasions. 9 , low $\mathrm{K}^{+}(5 \mathrm{mM} \mathrm{KCl})$; $\mathrm{O}$, high $\mathrm{K}^{+}(50 \mathrm{mM} \mathrm{KCl})$. 


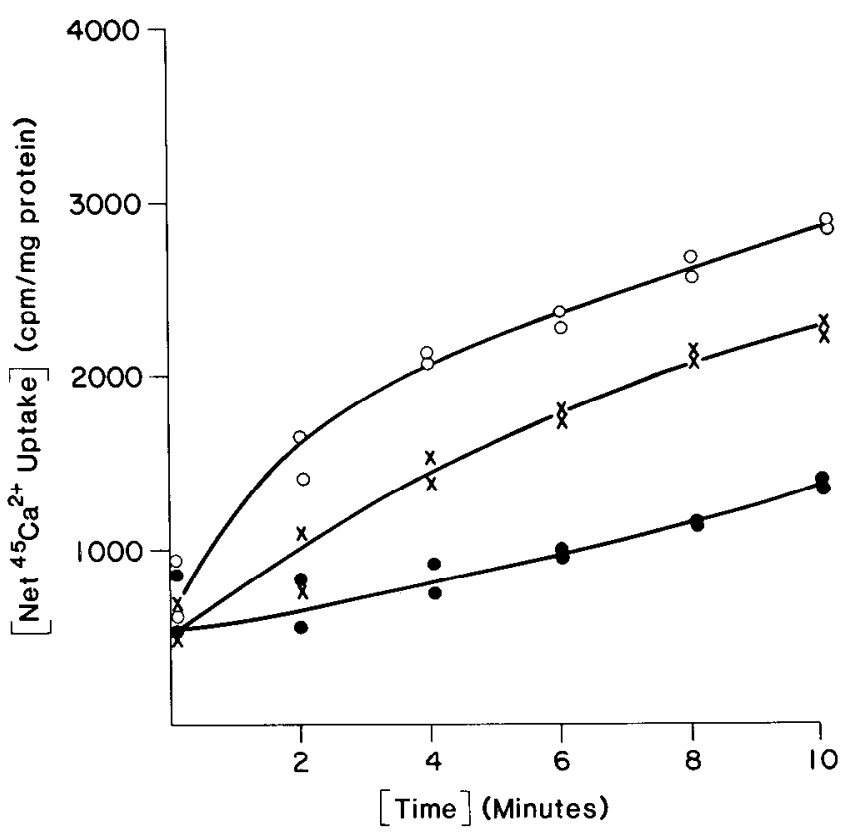

Figure 6. Effect of veratridine on ${ }^{4 b} \mathrm{Ca}^{2+}$ uptake into NCB20 cells. Veratridine $(10 \mu \mathrm{M})$ was added to low $\mathrm{K}^{+}$media $(5 \mathrm{mM}$ $\mathrm{KCl})$ at the start of the incubation period. Cells were assayed as previously described. $X$, low $\mathrm{K}^{+}$buffer $+10 \mu \mathrm{M}$ veratridine; - low $\mathrm{K}^{+}$buffer; $O$, high $\mathrm{K}^{+}$buffer. Results are duplicate determinations and are representative of results obtained on three separate occasions.

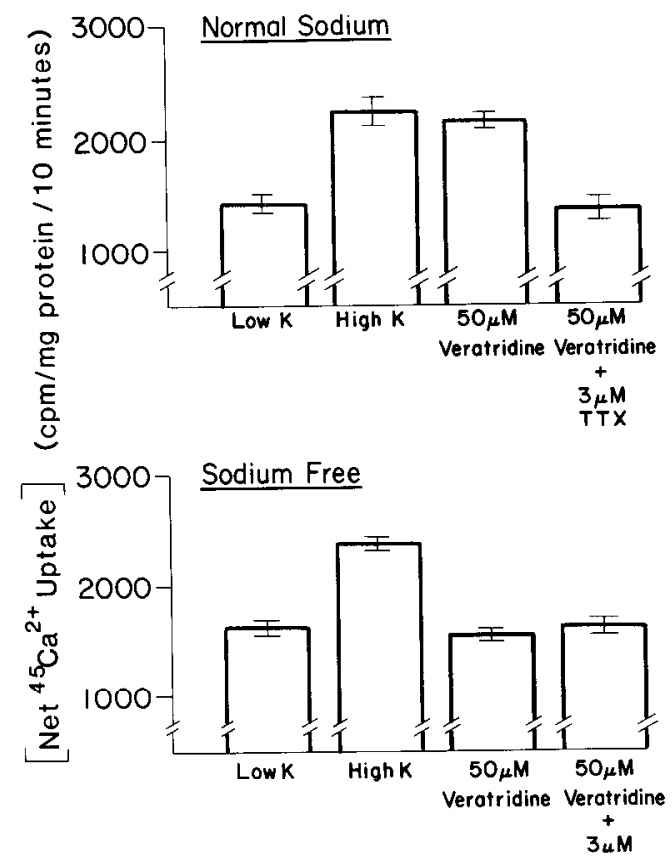

Figure 7. The effect of veratridine, tetrodotoxin (TTX), and sodium ions upon net ${ }^{45} \mathrm{Ca}^{2+}$ uptake into NCB-20 cells. Veratridine and tetrodotoxin were added to low $\mathrm{K}^{+}(5 \mathrm{mM} \mathrm{KCl})$ buffer at the concentrations indicated. In the experiments indicated, sodium-free, choline chloride-substituted media were used (see legend to Fig. 5).

$\mathrm{mM} \mathrm{K} \mathrm{K}^{+}$-induced depolarization, in the presence of $3 \mu \mathrm{M}$ TTX. This concurrent treatment would be expected to completely block all sodium channels in the cells. Under these conditions, batrachotoxin $(1 \mu \mathrm{M})$ did not reduce the depolarization-sensitive ${ }^{45} \mathrm{Ca}^{2+}$ uptake into NCB-20 cells (Fig. 9). Thus, batrachotoxin does not block the type of VSCC assayed in these cultured cells.

Effect of differentiation upon VSCCs. In our initial experiments, we observed that the NCB-20 cells, which produced the largest depolarization-sensitive ${ }^{45} \mathrm{Ca}^{2+}$ uptake, appeared the most differentiated (see above). In contrast, NG108-15 cells, which produced the smallest response, appeared least differentiated.

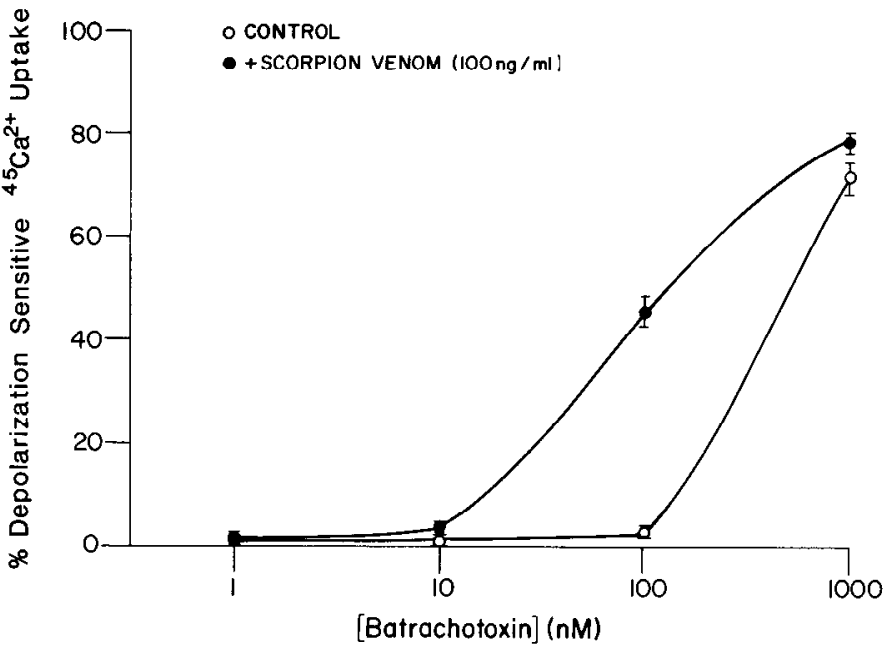

Figure 8. Enhancement of batrachotoxin-stimulated net ${ }^{45} \mathrm{Ca}^{2+}$ uptake into NCB-20 cells by scorpion venom (100 ng/ $\mathrm{ml})$. Drugs were added to low $\mathrm{K}^{+}(5 \mathrm{mM} \mathrm{KCl})$ media at the start of the incubation period. Cells were assayed as previously described. Results are expressed as the percentage of maximal uptake of ${ }^{45} \mathrm{Ca}^{2+}$ compared with high $\mathrm{K}^{+}(50 \mathrm{mM} \mathrm{KCl})$-stimulated uptake. Results are mean \pm SEM of quadruplicate determinations.

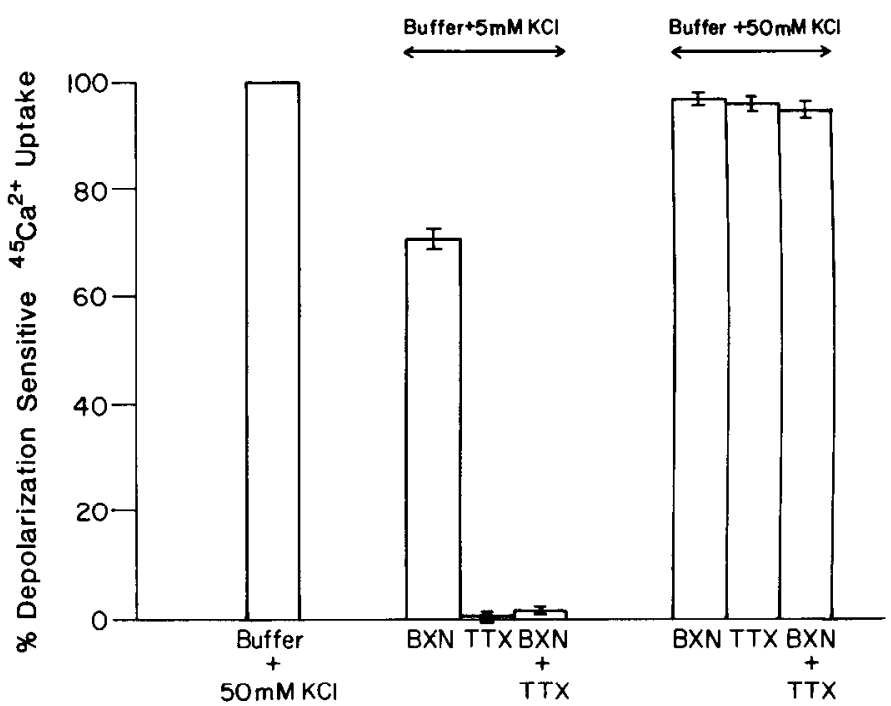

Figure 9. Can batrachotoxin selectively block VSCCs in NCB-20 cells? Batrachotoxin $(B X N)(1 \mu \mathrm{M})$ and tetrodotoxin $(T T X)(3 \mu \mathrm{M})$ were added to either low $\mathrm{K}^{+}(5 \mathrm{mM} \mathrm{KCl})$ or high $\mathrm{K}^{+}$(50 mM KCl) media as indicated. Net ${ }^{45} \mathrm{Ca}^{2+}$ uptake was measured as previously described. Results are expressed as a percentage of the maximal uptake of ${ }^{45} \mathrm{Ca}^{2+}$ produced by $50 \mathrm{mM}$ $\mathrm{KCl}$. The values are mean $\pm \mathrm{SEM}$ of quadruplicate determinations. 
Previously, it has been shown that ncuroblastoma cells can be induced to differentiate by agents which raise intracellular cAMP concentrations (Daniels and Hamprecht, 1974). Therefore, in the present study, the effect of differentiation upon VSCCs in neuroblastoma cells was examined.

In preliminary studies, cultures of cells were treated for periods of up to 5 days with $10 \mu \mathrm{M}$ prostaglandin $\mathrm{E}_{1}$ $\left(\mathrm{PGE}_{1}\right)$ and $50 \mu \mathrm{M}$ IBMX, a treatment which raises intracellular cAMP levels between 10 - and 100 -fold (Berry-Kravis and Dawson, 1984). This treatment was found to produce morphological differentiation of both NCB-20 and NG108-15 cells (Fig. 10). Typically, differentiated cells were larger than control cells and had long, thick, neurite-like processes. Cell-cell contact was increased and treatment additionally produced the development of many short branching processes. Cell division decreased following treatment.

Differentiation of NG108-15, NCB-20, and N4TG1 cells with $10 \mu \mathrm{M} \mathrm{PGE}_{1}$ (or $1 \mathrm{mM}$ dibutyryl cAMP) and $50 \mu \mathrm{M}$ IBMX for 4 days produced an increase in depolarization-induced ${ }^{45} \mathrm{Ca}^{2+}$ uptake (Fig. 11 ). This effect appeared to consist of an increase in the initial rate of uptake. It appears that in NG108-15 cells, the intracellular levels of ${ }^{45} \mathrm{Ca}^{2+}$ at steady state were also increased following differentiation. The cell lines differed in the extent that each was altered by differentiation. In particular, NG108-15 cells appeared to have the largest inducible depolarization-sensitive uptake after differentiation, followed by N4TG1 cells. Uptake in NCB-20 cells was generally less enhanced than in the other two lines. The induction of voltage-sensitive uptake in NG108-15 cells was apparent $24 \mathrm{hr}$ after treatment with $\mathrm{PGE}_{1}$ and IBMX and increased linearly for $96 \mathrm{hr}$ (Fig. 12). The low $\mathrm{K}^{+}$(basal) ${ }^{45} \mathrm{Ca}^{2+}$ uptake was only marginally affected by this treatment.

Depolarization-sensitive calcium uptake was induced by a variety of agents that raise intracellular cAMP levels. Thus, $\mathrm{PGE}_{1}(10 \mu \mathrm{M})$, cholera toxin $(1 \mu \mathrm{g} / \mathrm{ml})$, and forskolin $(1 \mu \mathrm{M})$, which increase intracellular cAMP levels, all produced significant increases in depolarizationsensitive ${ }^{45} \mathrm{Ca}^{2+}$ uptake (Fig. 13). The phosphodiesterase inhibitor, IBMX, at a dose of $50 \mu \mathrm{M}$, did not produce a significant effect when incubated alone with cells. However, this concentration produced an enhancement of the responses to both $\mathrm{PGE}_{1}$ and forskolin and, additionally, was required for the expression of an effect with cholera toxin (Fig. 13). Direct manipulation of intracellular cAMP levels by preincubation of cells with $1 \mathrm{mM}$ dibutyryl cAMP produced an increase in depolarization-sensitive ${ }^{45} \mathrm{Ca}^{2+}$ uptake equivalent to that seen with $\mathrm{PGE}_{1}$.

Two other methods have been shown to cause differentiation of some cultured cells. Dimethylsulfoxide (DMSO) has been shown by several workers to produce morphological differentiation (Jacques et al., 1981). In the present study, treating cells with $1.5 \%$ DMSO produced both a pronounced morphological response and a large increase in depolarization-sensitive ${ }^{45} \mathrm{Ca}^{2+}$ uptake. In contrast, serum deprivation (from $10 \%$ to $1 \%$ ), which has been shown in several laboratories to produce a cellular differentiation, did not produce either a morphological response or an effect on ${ }^{45} \mathrm{Ca}^{2+}$ uptake.
The increase in depolarization-sensitive ${ }^{45} \mathrm{Ca}^{2+}$ uptake could be explained by several mechanisms. The ${ }^{45} \mathrm{Ca}^{2+}$ could enter the cell via voltage-sensitive $\mathrm{Na}^{+}$channels or by $\mathrm{Na}^{+} / \mathrm{Ca}^{2}$ exchange, as well as by VSCCs. In order to verify that the increase in depolarization-sensitive ${ }^{45} \mathrm{Ca}^{2+}$ uptake was through VSCCs, a variety of ${ }^{40} \mathrm{Ca}^{2+}$ channel blockers were examined. From Figure 14, it can be seen that the depolarization-induced ${ }^{45} \mathrm{Ca}^{2+}$ uptake in differentiated NG108-15 cells was blocked by nitrendipine $\left(\mathrm{IC}_{50}=7 \mathrm{nM}\right), \mathrm{D}-600\left(\mathrm{IC}_{50}=690 \mathrm{nM}\right)$, and diltiazem $\left(\mathrm{IC}_{50}=1600 \mathrm{nM}\right)$. Thus, the characteristics of the depolarization-induced uptake of ${ }^{45} \mathrm{Ca}^{2+}$ in differentiated NG108-15 cells appear similar to those described in detail above for NCB-20 cells.

\section{Discussion}

This study has identified VSCCs in selected neuronal clonal cell lines. ${ }^{45} \mathrm{Ca}^{2+}$ uptake was stimulated by conditions which produce a depolarization in cells (Nachshen and Blaustein, 1979; Jacques et al., 1981). In particular ${ }^{45} \mathrm{Ca}^{2+}$ uptake was stimulated by increasing $\left[\mathrm{K}^{+}\right]_{0}$ from $5 \mathrm{~mm}$ to $50 \mathrm{~mm}$ and by alkaloid neurotoxins which produce depolarization by increasing sodium conductance (Catterall, 1975). Depolarizaton-induced increase of ${ }^{45} \mathrm{Ca}^{2+}$ uptake does not necessarily signify the presence of VSCCs. Thus, ${ }^{45} \mathrm{Ca}^{2+}$ could enter the cell through "fast" sodium channels or else via $\mathrm{Na}^{+} / \mathrm{Ca}^{2+}$ exchange following a depolarization-induced influx of $\mathrm{Na}^{+}$. However, various experiments indicate that this is not the case in the present situation. Specificity of the response was shown by the lack of sensitivity of the uptake to agents which block voltage-sensitive $\mathrm{Na}^{+}$channels, such as TTX, and to agents such as apamin, TEA, and 4aminopyridine, which block potassium channels. Conversely, the uptake was extremely sensitive to blockade by both a variety of divalent cations and organic calcium channel antagonists. Indeed, the specificity of the VSCCs defined in these clonal cells appears to be very similar to that found in smooth muscle. This is particularly true with regard to the very high affinity of the organic calcium-blocking drugs for the channels in both cultured cells and smooth muscle. The channels are also somewhat similar to those in cardiac muscle, although these appear to have somewhat lower affinities for organic calcium blockers (Lee and Tsien, 1983). The VSCCs in cultured neuronal cells are clearly different from those previously described in nerve tissue (Starke and Schümann, 1973; Van der Kloot and Kita, 1975; Högestätt et al., 1982). These have been reported not to be blocked at all by calcium antagonists except at very high nonspecific concentrations. In addition to those cell lines described here, we have also characterized similar VSCCs in several other lines in a preliminary fashion. These include the adrenergic/cholinergic hybrid NII15-CA2 (Heumann et al., 1979). However, such VSCCs do not occur in all cell lines. For example, we have not detected them in the human neuroblastoma MC9C, irrespective of growth conditions.

Our ability to measure voltage-sensitive ${ }^{45} \mathrm{Ca}^{2+}$ accumulation in cultured cells indicates that these channels must remain open for a considerable period of time. Indeed, we could not detect a complete inactivation of 

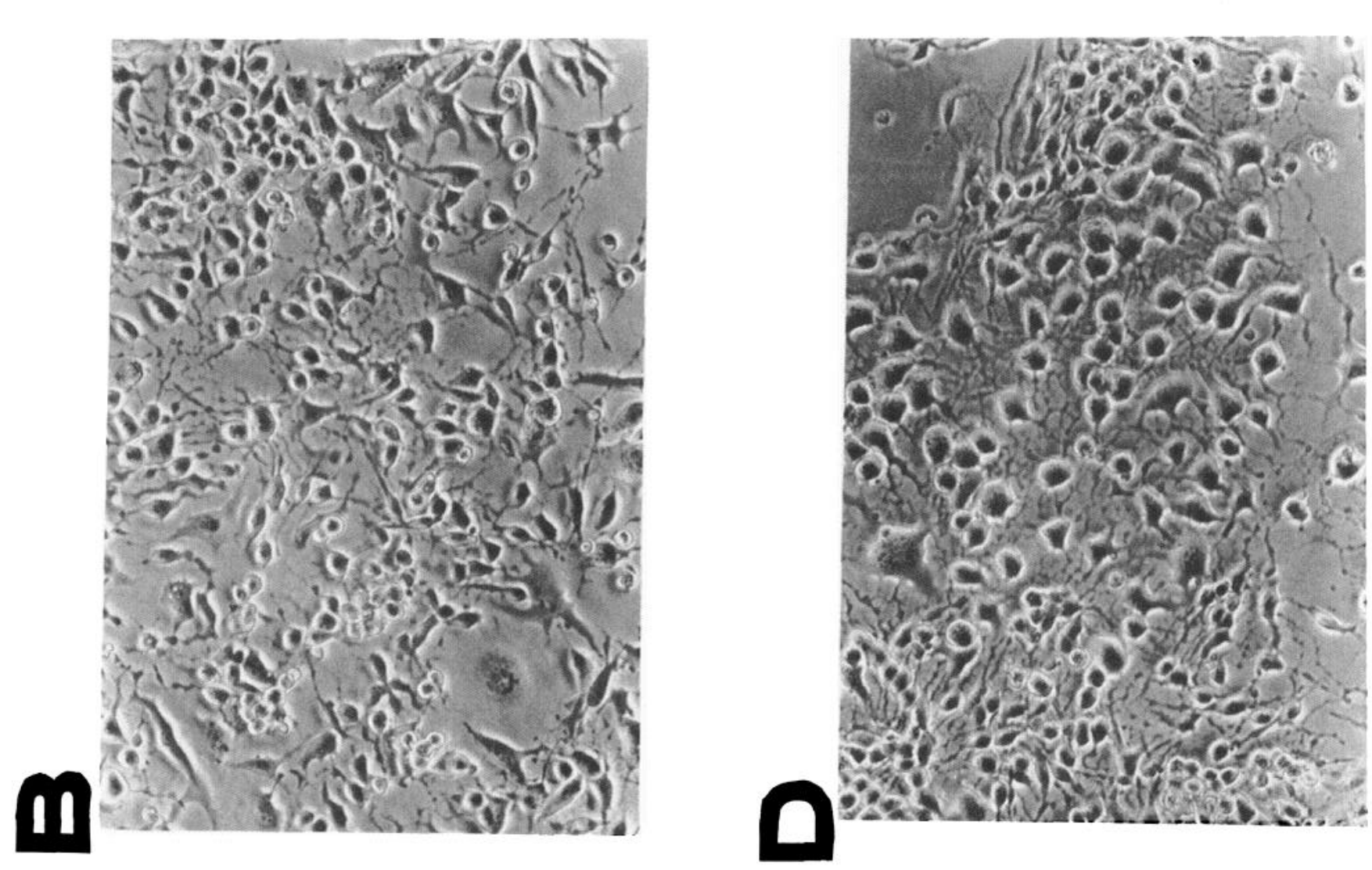

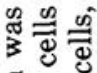

10.2017)

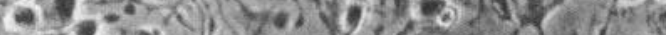

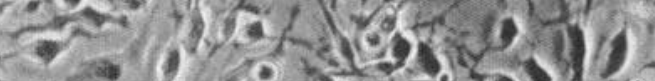

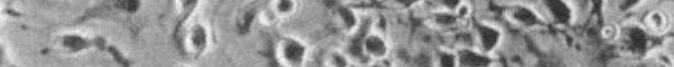

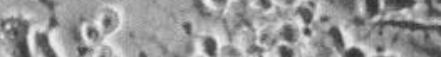
$a=24,0$.
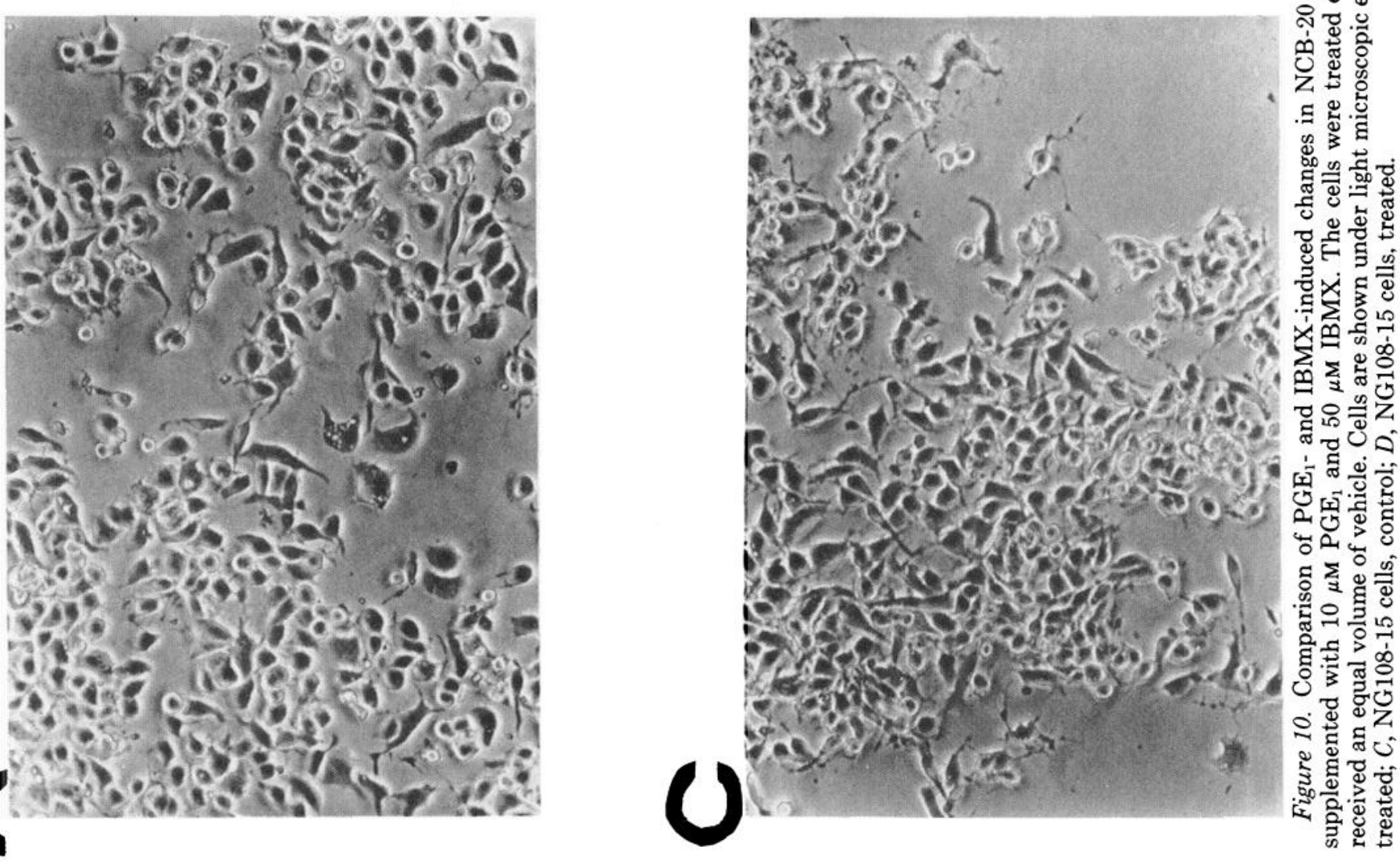


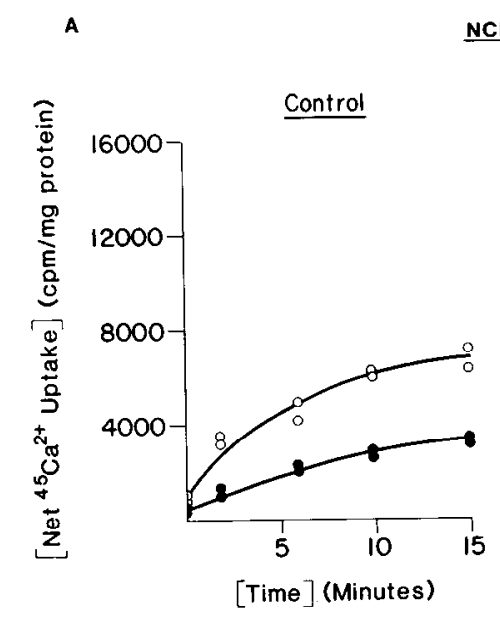

NCB-20

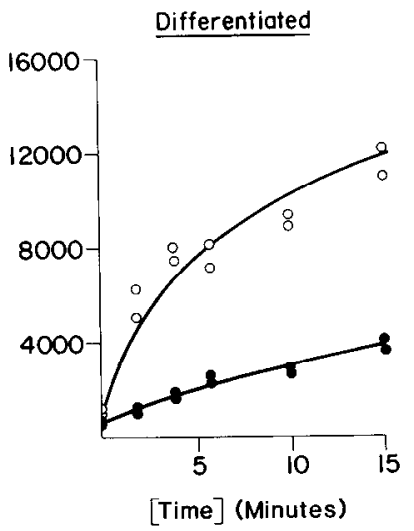

B

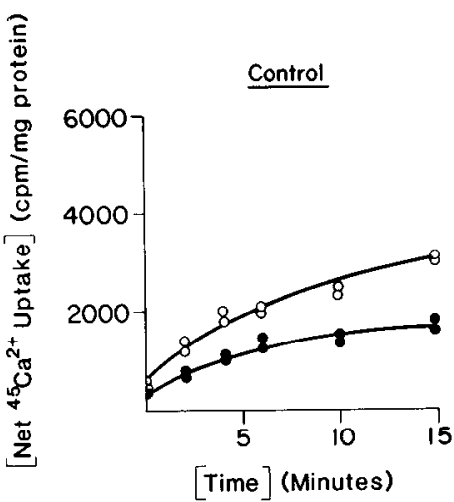

N4TG1

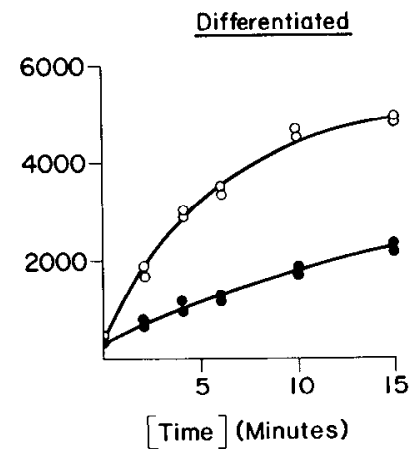

c

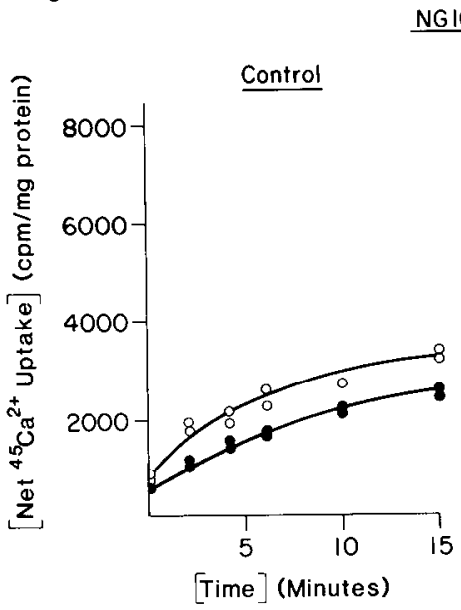

NG108-15

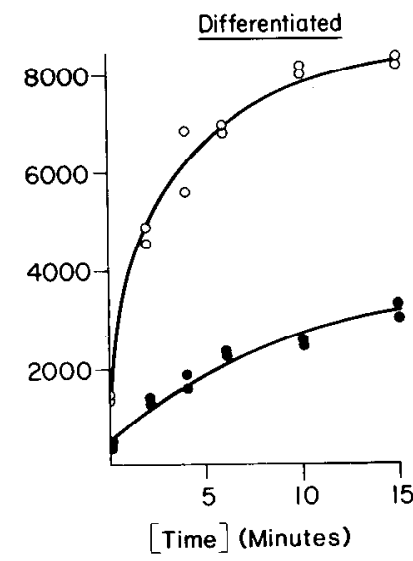

Figure 11. Effect of cellular differentiation upon net ${ }^{45} \mathrm{Ca}^{2+}$ uptake into $(A)$ NCB-20 cells, $(B)$ N4TG1 cells, and $(C)$ NG108-15 cells. Cells were grown in the presence of $10 \mu \mathrm{M}$ $\mathrm{PGE}_{1}$ (or $1 \mathrm{mM}$ dibutyryl cAMP) and $50 \mu \mathrm{M}$ IBMX as described in the legend to Figure 10 . Net ${ }^{45} \mathrm{Ca}^{2+}$ uptake was measured in the presence of either low $\mathrm{K}^{+}(5 \mathrm{mM} \mathrm{KCl})(\boldsymbol{O})$ or high $\mathrm{K}^{+}(50$ $\mathrm{mM} \mathrm{KCl)} \mathrm{(O)} \mathrm{as} \mathrm{previously} \mathrm{described.} \mathrm{Results} \mathrm{are} \mathrm{expressed} \mathrm{as}$ net ${ }^{45} \mathrm{Ca}^{2+}$ uptake per milligram of protein. Each point represents a single experimental determination. The experiment was replicated on at least two separate occasions.

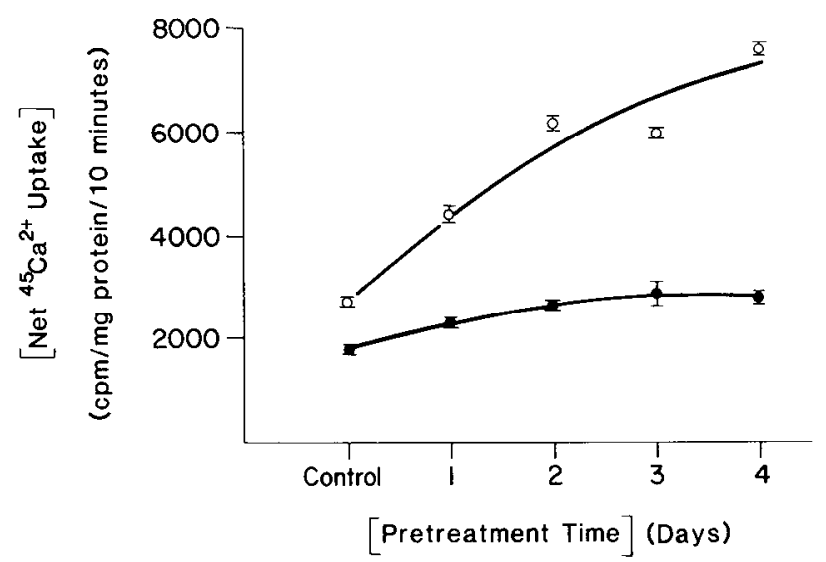

Figure 12. Time course of the response of NG108-15 cells to $\mathrm{PGE}_{1}(10 \mu \mathrm{M})$ and IBMX $(50 \mu \mathrm{M})$. Growing cells were supplemented with $\mathrm{PGE}_{1}$ and IBMX for the times indicated. Cells were assayed for ${ }^{45} \mathrm{Ca}^{2+}$ uptake over a 10 -min period as previously described. Results are expressed as counts per minute of ${ }^{45} \mathrm{Ca}^{2+}$ uptake per milligram of protein per $10 \mathrm{~min}$. Each point represents the mean \pm SEM of five experimental determinations.

the VSCCs over the time course of our studies. There is no consensus at present as to the inactivation characteristics of VSCCs in different cells. Thus, VSCCs appear to undergo true voltage-dependent inactivation, inactivation resulting from accumulation of intracellular $\mathrm{Ca}^{2+}$, or no inactivation at all, depending on the tissue studied (Ashcroft and Stanfield, 1982; Hagiwara and Ohmori, 1982; Fukushima and Hagiwara, 1983). Moreover, in some cases, such as cardiac Purkinje fibers, a proportion of the VSCCs inactivate, leaving a residue which does not (Kass et al., 1976). Thus, there is a precedent for the existence of VSCCs which remain open for long periods of time in response to depolarizing stimuli.

The inhibitory potency of the divalent cations in the present study is similar to that reported elsewhere (Hagiwara and Byerly, 1981). In contrast to organic antagonists, the divalent metal cations also inhibited basal ${ }^{45} \mathrm{Ca}^{2+}$ uptake at higher concentrations, indicating that these ions have a variety of other actions on calciummediated processes within cells. Both barium and strontium have been shown to pass easily through VSCCs (Hagiwara and Byerly, 1981; Nachshen and Blaustein, 1981) and, interestingly, strontium showed only moderate ability to block ${ }^{45} \mathrm{Ca}^{2+}$ uptake. Lanthanide series trivalent ions, such as $\mathrm{La}^{3+}$ and $\mathrm{Gd}^{3+}$, actually enhanced the uptake of ${ }^{45} \mathrm{Ca}^{2+}$ by the cells. However, the effects of these ions on VSCCs and transmitter release are clearly complex. Although they clearly block VSCCs in some cases, they also enhance basal spontaneous release of transmitter and even substitute for $\mathrm{Ca}^{2+}$ in supporting evoked transmitter release in some cases (Heuser and Miledi, 1971; Ng et al., 1982).

'The most compelling evidence that we have identified one type of VSCC relates to the effects of organic calcium channel blockers. Thus, a wide variety of compounds, that have been suggested as having calcium channelblocking activity, all potently inhibited voltage-sensitive 

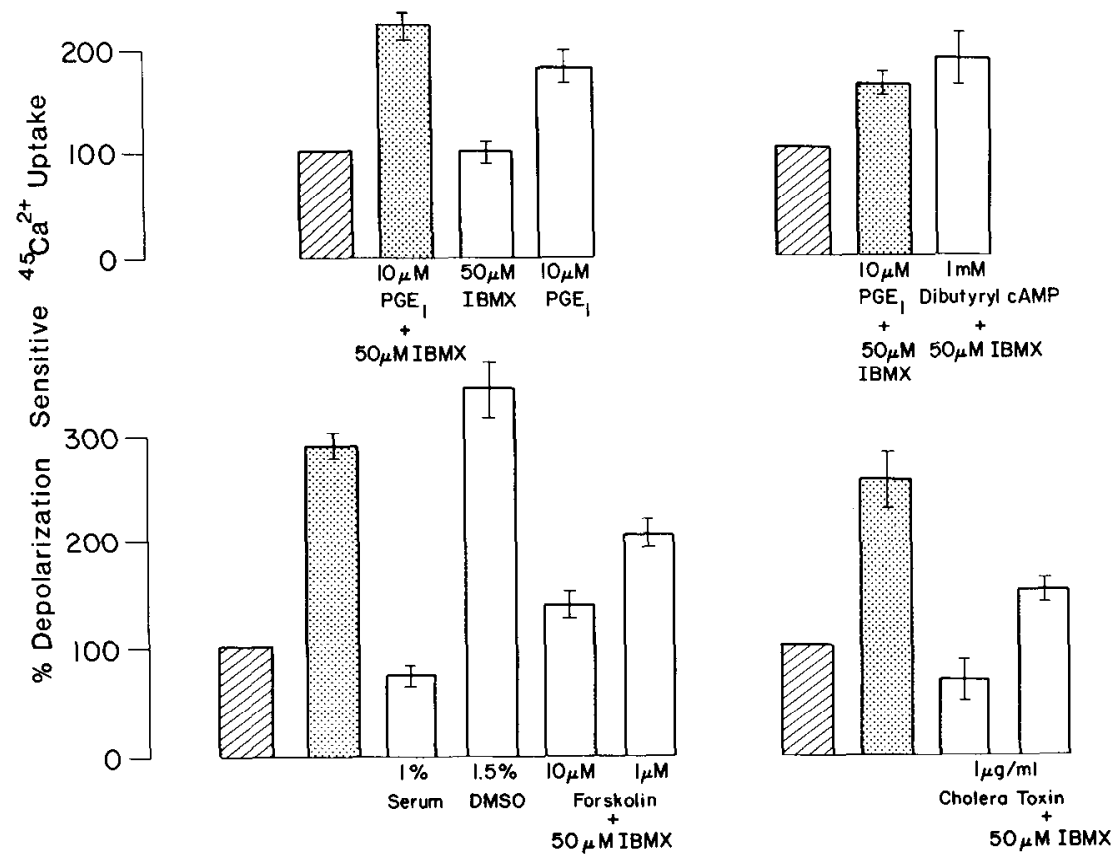

Figure 13. Effect of cAMP elevating agents upon depolarization-sensitive ${ }^{45} \mathrm{Ca}^{2+}$ uptake into NG108-15 cells. Cells were treated for 4 days with the respective concentration of drug. Protocol for treatment was similar to that described in the legend to Figure 12. Cells were assayed for depolarization-sensitive ${ }^{45} \mathrm{Ca}^{2+}$ uptake with low $\mathrm{K}^{+}(5 \mathrm{mM} \mathrm{KCl})$ and high $\mathrm{K}^{+}(50 \mathrm{mM} \mathrm{KCl})$ media during 10-min incubations. Blanks (zero time points) were routinely subtracted from results. The depolarization-sensitive component was estimated as the difference between the low and high $\mathrm{K}^{+}$uptake. The depolarization-sensitive uptake in untreated cells is taken as $100 \%$. The depolarization-sensitive uptake in treated cells is expressed as a percentage of this value. Results are mean \pm SEM of quadruplicate determinations performed in a minimum of two separate occasions. Hatched bars represent control cells; stippled bars represent PGF $\mathrm{CF}_{1}(10 \mu \mathrm{M})$ and IBMX $(50 \mu \mathrm{M})$ treated. The results have been presented as four separate groups of experiments, each with their respective controls. It should be noted that the degree of response to $\mathrm{PGE}_{1}$ and IBMX was somewhat variable between batches of cells.

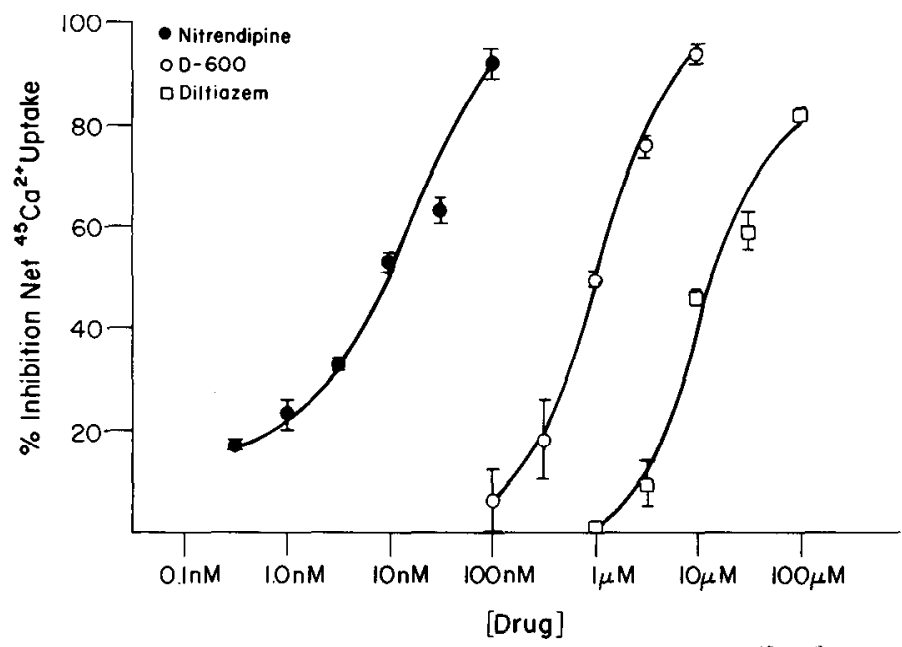

Figure 14. Inhibition of depolarization-sensitive ${ }^{45} \mathrm{Ca}^{2+}$ uptake in treated NG108-15 cells. Cells were treated for 4 days with $\mathrm{PGE}_{1}(10 \mu \mathrm{M})$ and IBMX $(50 \mu \mathrm{M})$ as described previously. Inhibition studies with nitrendipine $(O), D-600(O)$, and diltiazem (ঢ) were performed as described in the legend to Figure 3 . Each point represents mean \pm SEM of quadruplicate determinations, performed on a minimum of two separate occasions.

${ }^{45} \mathrm{Ca}^{2+}$ uptake, while having no effect on basal uptake within the same concentation range. The dihydropyridines, which block the voltage-sensitive component at nanomolar concentrations, are certainly the most spe- cific agents yet developed for blocking VSCCs. The rank order of potency of these compounds in this assay is similar to that seen in a variety of smooth muscle preparations (Bolger et al., 1982). This potency comparison also extends to the phenylalkylamines, such as verapamil and D-600, and the diphenylalkylamines, such as cinnarizine, which were approximately 1000 -fold weaker than the dihydropyridines. Importantly, the affinity of verapamil and $\mathrm{D}-600\left(\mathrm{IC}_{50}=1800 ; 300 \mathrm{nM}\right)$ is within the low concentration range where their actions are specific for VSCCs. This specificity is confirmed by the stereoselectivity of both verapamil and nimodipine, the $(-)$-enantiomers being more potent than the respective $(+)$-enantiomers. This corresponds to data reported previously by other workers (Jim et al., 1981; Towart et al., 1982; Triggle, 1982; Murphy et al., 1983). This is an important consideration, since Triggle (1982) and others have suggested that the nonspecific actions of these compounds, e.g., on blocking sodium channels or neurotransmitter receptors, do not express stereoselectivity.

Our studies has also provided indirect evidence that voltage-sensitive sodium channels are present in NCB20 cells. Thus alkaloid neurotoxic agents, such as veratridine and batrachotoxin, were able to produce a $\mathrm{Na}^{+}$dependent cellular depolarization resulting in the opening of VSCCs. The sensitivity of the response to scorpion venom and TTX is consistent with the model proposed by Catterall (1980), whereby these substances are 
thought to act at different binding sites within the sodium channel.

Recently, Romey and Lazdunski (1982) suggested that batrachotoxin $\left(2 \times 10^{-7} \mathrm{M}\right)$ and veratridine $\left(2 \times 10^{-4} \mathrm{M}\right)$ could block VSCCs measured electrophysiologically in differentiated N1E-115 neuroblastoma cells. In our biochemical studies, $50 \mathrm{mM} \mathrm{K}{ }^{+}$-induced ${ }^{45} \mathrm{Ca}^{2+}$ uptake was not inhibited by batrachotoxin at micromolar concentrations. Thus, it is clear that VSCCs of the sort described in the present studies are not blocked by batrachotoxin. It is conceivable, however, that VSCCs may be of several distinct types (see below), and the possibility remains that batrachotoxin may act as an antagonist of another type.

Our results appear to be qualitatively similar to those reported by both Stallcup (1979) and Ritchie (1979), who have demonstrated VSCCs and voltage-sensitive sodium channels in PC12 cells. In a more recent study, Toll (1982) has investigated the pharmacology of the VSCCs in these cells and has found them to be potently blocked by dihydropyridines in the nanomolar concentration range. Thus, the $\mathrm{PC} 12$ cells and the neuroblastoma cells reported in this study and in a preliminary report by Takahashi and Ogura (1983) represent the first demonstration of dihydropyridine-sensitive VSCCs in neuronal tissue. These results, in general, contrast with those reported by others using synaptosomes (Nachshen and Blaustein, 1979). High $\mathrm{K}^{+}$-stimulated ${ }^{45} \mathrm{Ca}^{2+}$ uptake in synaptosomal preparations was not inhibited by dihydropyridines at very high concentrations and was only blocked by verapamil and D-600 at enormous concentrations where nonspecific effects of these compounds clearly occur (Baker et al., 1973; Galper and Catterall, 1979; McGee and Schneider, 1979; Nachshen and Blaustein, 1979; Karliner et al., 1982; Quirion and Pert, 1982). 'I'hese results are intriguing since, recently, several work. ers have identified high affinity ${ }^{3} \mathrm{H}$-nitrendipine binding sites (nanomolar affinity) in synaptosomes (Ehlert et al., 1982). These, together with other results on ${ }^{3} \mathrm{H}$-dihydropyridine binding sites in neurons, pose several interesting questions. It seems unlikely that these sites are artifacts since their properties are similar to those in smooth muscle, a tissue in which ${ }^{3} \mathrm{H}$-nitrendipine binding sites correspond closely to VSCCs. Moreover, autoradiographic studies suggest that these binding sites in brain are localized neuronally (Murphy et al., 1982) rather than to cerebral blood vessels.

It seems likely that the VSCCs measured in cultured clonal nerve cell lines represent the functional correlate of the ${ }^{3} \mathrm{H}$-nitrendipine binding sites detected in brain. Such VSCCs presumably do not function to provide ${ }^{45} \mathrm{Ca}^{2+}$ for transmitter release as stimulus/secretion coupling in neuronal tissue is not blocked by organic calcium blockers at appropriate concentrations. Unfortunately, in most investigations of neuronal VSCCs measured electrophysiologically in the cell soma or dendrites, the pharmacology of the calcium current is unknown. Clearly it is not sufficient to observe, as is often the case, that a calcium current is blocked by $100 \mu \mathrm{M}$ verapamil or $\mathrm{D}$ 600 , a concentration at which these drugs are completely nonspecific in their effects and inhibit virtually all known biological processes. It remains unknown whether some of these calcium currents are also blocked by low concentrations of dihydropyridines. Clearly this is a far better pharmacological criterion for assessing the presence of calcium channels than the use of high concentrations of verapamil.

One important feature of the VSCCs that we have identified concerns their association with the state of cellular differentiation. We have confirmed findings by other workers, that a variety of agents can induce NG108-15 cells to undergo a morphological and biochemical differentiation. In addition, we have extended this result to both the NCB-20 cell line and N4TG1. Many other cellular responses appear to change following differentiation, including an increase in acetylcholinesterase and choline acetyltransferase activity in NG108-15 cells (Hamprecht, 1977), and the emergence of depolarization-sensitive release of acetylcholine (McGee et al., 1978). Agents that directly or indirectly increase intracellular cAMP levels appear to regulate both differentiation and VSCC activity. It is possible that cAMP-dependent phosphorylation directly modulates channel activity as is probably the case in the heart. However, this seems unlikely due to the time course of the response. The increase in VSCC activity does not appear to be significant for at least $12 \mathrm{hr}$ (unpublished observations), whereas a phosphorylation-mediated effect would be expected within minutes. At present, our results do not distinguish between an increase in numbers of VSCCs or a long-term change in the conductance of a constant number of VSCCs. Studies on ${ }^{3} \mathrm{H}$-nitrendipine binding would be expected to answer this question.

Our results clearly identify one type of VSCC present in clonal neuronal cells as characterized pharmacologically. These and other studies discussed here support the hypothesis that VSCCs in nerves may be heterogeneous with respect to their pharmacology in addition to their kinetic characteristics.

\section{References}

Ashcroft, F. M., and P. R. Stanfield (1982) Calcium inactivation in skeletal muscle fibres of the stick insect Carausius morosus. J. Physiol. (Lond.) 330: 349-372.

Avrach, J., and D. F. H. Wallach (1971) Preparation and properties of plasma membrane and endoplasmic reticulum fragments from isolated rat fat cells. Biochim. Biophys. Acta 233: $334-345$

Baker, P. F., H. Meves, and E. B. Ridgeway (1973) Effects of manganese and other agents on the calcium uptake that follows depolarization of squid axons. J. Physiol. (Lond.) 231: $511-526$.

Bellemann, P., D. Ferry, F. Lübbecke, and H. Glossmann (1981) ${ }^{3} \mathrm{H}$-Nitrendipine, a potent calcium antagonist, binds with high affinity to cardiac membranes. Arzneim. Forsch. 31: 2064-2067.

Berry-Kravis, E., and G. Dawson (1984) Modulation of an adenylate cyclase linked serotonin $(5 \mathrm{HT})$ receptor system in a neuroblastoma/brain explant hybrid cell line (NCB-20), by opiates, prostaglandins, and $\alpha_{2}$-adrenergic agonists. In CNS Receptors, from Molecular Pharmacology to Behaviour, P. Mandel and F. DeFendis, eds., Raven Press, New York, in press.

Bolger, G. T., P. T. Gengo, E. M. Luchowski, H. Siegel, D. J. Triggle, and R. A. Janis (1982) High affinity binding of a calcium channel antagonist to smooth and cardiac muscle. 
Biochem. Biophys. Res. Commun. 104: 1604-1609.

Campbell, T. J., and E. M. Vaughan Williams (1982) Electrophysiological and other effects on rabbit hearts of CCI22277, a new steroidal antiarrhythmic drug. Br. J. Pharmacol. 76: $337-345$

Catterall, W. A. (1975) Activation of the action potential $\mathrm{Na}^{+}$ ionophore of cultured neuroblastoma cells by veratridine and batrachotoxin. J. Biol. Chem. 250: 4053-4059.

Catterall, W. A. (1980) Neurotoxins that act on voltage-sensitive sodium channels in excitable membranes. Annu. Rev. Pharmacol. Toxicol. 20: 15-43.

Connor, C. G., R. Levin, and B. L. Brownstein (1982) The effects of trifluoperazine on calcium uptake and calciumdependent functions in cultured epithelial cells. Biol. Cell. 46: 37-42.

Daniels, M. P., and B. Hamprecht (1974) The ultrastructure of neuroblastoma glioma somatic cell hybrids. J. Cell. Biol. 63: 691-699.

Ehara, T., and R. Kaufmann (1978). The voltage- and timedependent effects of $(-)$-verapamil on the slow inward current in isolated cat ventricular myocardium. J. Pharmacol. Exp. Ther. 207: 49-55.

Ehlert, F. J., W. R. Roeske, E. Itoga, and H. I. Yamamura (1982) The binding of "II-nitrendipine to receptors for calcium channel antagonists in the heart, cerebral cortex and ileum of rats. Life Sci. 30: 2191-2202.

Erdreich, A., R. Spanier, and H. Rahamimoff (1983) The inhibition of $\mathrm{Na}$-dependent $\mathrm{Ca}$ uptake by verapamil in synaptic plasma membrane vesicles. Eur. J. Pharmacol. 90: 193-202.

Fairhurst, A. S., S. A. Thayer, J. E. Colker, and D. A. Beatty (1983) A calcium antagonist drug binding site in skeletal muscle sarcoplasmic reticulum: Evidence for a calcium channel. Life Sci. 32: 1331-1339.

Flaim, S. F. (1982) Comparative pharmacology of calcium blockers based on studies of vascular smooth muscle. In Calcium Blockers: Mechanisms of Action and Clinical Applications, S. F. Flaim and R. Zelis, eds., pp. 155-178, Urban Schwarzenberg, Munich.

Fleckenstein, A. (1977) Specific pharmacology of calcium in myocardium, cardiac pacemakers, and vascular smooth muscle. Annu. Rev. Pharmacol. Toxicol. 17: 149-166.

Fosset, M., E. Jaimovich, E. Delpont, and M. Lazdunski (1983) ${ }^{3} \mathrm{H}$-Nitrendipine receptors in skeletal muscle. J. Biol. Chem. 258: 6086-6092.

Fukushima, Y., and S. Hagiwara (1983) Voltage-gated $\mathrm{Ca}^{2+}$ channel in mouse myeloma cells. Proc. Natl. Acad. Sci. U. S. A. $80: 2240-2242$.

Galper, J. B., and W. A. Catterall (1979) Inhibition of sodium channels by D-600. Mol. Pharmacol. 15: 174-176.

Gould, R. J., K. M. M. Murphy, and S. H. Snyder (1982) ${ }^{3} \mathrm{H}-$ Nitrendipine-labelled calcium channels discriminate inorganic calcium agonists and antagonists. Proc. Natl. Acad. Sci. U. S. A. 79: 3656-3660.

Haeusler, G. (1972) Differential effect of verapamil on excitation-contraction coupling in smooth muscle and on excitation-secretion coupling in adrenergic nerve terminals. J. Pharmacol. Exp. Ther. 180: 672-682.

Hagiwara, S., and L. Byerly (1981) Calcium channel. Annu. Rev. Neurosci. 4: 69-125.

Hagiwara, S., and H. Ohmori (1982) Studies of calcium channels in rat clonal pituitary cells with patch electrode voltage clamp. J. Physiol. (Lond.) 331: 231-262.

Hamprecht, B. (1977) Structural, electrophysiological, biochemical and pharmacological properties of neuroblastomaglioma cell hybrids in culture. Int. Rev. Cytol. 49: 99-170.

Henry, P. D. (1980) Comparative pharmacology of calcium antagonists: Nifedipine, verapamil and diltiazem. Am. J. Cardiol. 46: 1047-1058.
Hescheler, J,, D. Pelzer, G. Trube, and W. Trautwein (1982) Does the organic calcium channel blocker D600 act from inside or outside on the cardiac cell membrane? Pflügers Arch. 393: 287-291.

Heumann, R., M. Ocalan, V. Kachel, and B. Hamprecht (1979) Clonal hybrid cell lines expressing cholinergic and adrenergic. properties. Proc. Natl. Acad. Sci. U. S. A. 76: 4674-4677.

Heuser, J., and R. Miledi (1971) Effect of lanthanum ions on function and structure of frog neuromusuclar junctions. Proc. R. Soc. Lond. Biol. 179: 247-260.

Hille, B. (1968) Pharmacological modifications of the sodium channels of frog nerve. J. Gen. Physiol. 51: 199-219.

Högestätt, E. D., K.-E. Andersson, and L. Edvinsson (1982) Effects of nifedipine on potassium-induced contraction and noradrenaline release, in cerebral and extracranial arteries from rabbit. Acta Physiol. Scand. 114: 283-296.

Jacques, Y., C. Frelin, P. Vigne, G. Romey, M. Parjari, and M. Lazdunski (1981) Neurotoxins specific for the sodium channel stimulate calcium entry into neuroblastoma cells. Biochemistry 20: 6219-6225.

Jim, K., A. Harris, L. B. Rosenberger, and D. J. Triggle (1981) Stereoselective and non-stereoselective effects of D600 (methoxyverapamil) in smooth muscle preparations. Eur. J. Pharmacol. 76: 67-72.

Karliner, J. S., H. J. Motulsky, J. Dunlap, J. H. Brown, and P. A. Insel (1982) Verapamil competitively inhibits $\alpha_{1}$-adrenergic and muscarinic but not $\beta$-adrenergic receptors in rat myocardium. J. Cardiovasc. Pharmacol. 4: 515-520.

Kass, R. S., S. Sicgelbaum, and R. W. Tsien (1976) Incomplete inactivation of the slow inward current in cardiac Purkinje fibres. J. Physiol. (Lond.) 263: 127-128p.

Kostyuk, P. G., and O. A. Krishtal (1977) Effects of calcium and calcium-chelating agents on the inward and outward current in the membrane of mollusc neurones. J. Physiol. (Lond.) 270:569-580.

Lee, K. S., and R. W. Tsien (1983) Mechanism of calcium channel blockade by verapamil, D600, diltiazem and nitrendipine in single dialysed heart cells. Nature 302: 790-794.

Llinas, R., and M. Sugimori (1980) Electrophysiological properties of in vitro Purkinje cell somata in mammalian cerebellar slices. J. Physiol. (Lond.) 305: 171-195.

Lynch, J. J., and R. G. Rahwan (1982) Absence of blocking effects on cardiac slow calcium channels by the intracellular calcium antagonist 2- $n$-propyl-3-dimethylamino-5,6-methylenedioxyindene. Can. J. Physiol. Pharmacol. 60: 841-849.

Malagodi, M., and C. Y. Chiou (1974) Pharmacological evaluation of a new $\mathrm{Ca}^{2+}$ antagonist 8-(N-N-diethylamino)-octyl3,4,5-trimethoxybenzoate hydrochloride (TMB-8): Studies in smonth muscles. Fur. .J. Pharmacol. 27: 25-33.

Marangos, P. J., J. Patel, C. Miller, and A. M. Martino (1982) Specific calcium antagonist binding sites in brain. Life Sci. 31: $1575-1585$.

McGee, R., and J. E. Schneider (1979) Inhibition of high affinity synaptosomal uptake systems by verapamil. Mol. Pharmacol. 16: 877-885.

McGee, R., P. Simpson, C. Christian, M. Mata, P. Nelson, and M. Nirenberg (1978) Regulation of acetylcholine release from neuroblastoma $\times$ glioma hybrid cells. Proc. Natl. Acad. Sci. U. S. A. 75: 1314-1318.

Mertz, T. E., and H. R. Kaplan (1982) Pirmenol hydrochloride (Cl-845) and reference antiarrhythmic agents. Effects on early ventricular arrhythmias after acute coronary artery ligation in anaesthetized rats. J. Pharmacol. Exp. Ther. 223: $580-590$.

Moolenaar, W. H., and I. Spector (1979) The calcium current and the activation of a slow potassium conductance in voltage-clamped mouse neurobalstoma cells. J. Physiol. (Lond.) 292: $307-323$. 
Murphy, K. M. M., R. J. Gould, and S. H. Snyder (1982) Autoradioraphic visualization of ${ }^{3} \mathrm{H}$-nitrendipine binding sites in rat brain: Localization to synaptic zones. Eur. J. Pharmacol. 81: 517-519.

Murphy, K. M. M., R. J. Gould, B. L. Largent, and S. H. Snyder (1983) A unitary mechanism of calcium antagonist drug action. Proc. Natl. Acad. Sci. U. S. A. 80: 860-864.

Nachshen, D. A., and M. P. Blaustein (1979) The effects of some organic "calcium antagonists" on calcium influx in presynaptic nerve terminals. Mol. Pharmacol. 16: 579-580.

Ng, D., N. M. Shanbaky, and J. L. Borowitz (1982) Novel calcium channels used for Lanthanide ion-induced adrenal catecholamine release. Res. Commun. Chem. Pathol. Pharmacol. 37: 259-265.

Quirion, R., and C. B. Pert (1982) Certain calcium antagonists are potent displacers of $\left[{ }^{3} \mathrm{H}\right]$-phencyclidine (PCP) binding in rat brain. Eur. J. Pharmacol. 83: 155-156.

Ritchie, A. K. (1979) Catecholamine secretion in a rat pheochromocytoma cell line: Two pathways for calcium entry. J. Physiol. (Lond.) 286: 541-561.

Romey, G., and M. Lazdunski (1982) Lipid-soluble toxins thought to be specific for sodium channels block calcium channels in neuronal cells. Nature 297: 79-80.

Stallcup, W. B. (1979) Sodium and calcium fluxes in a clonal nerve cell line. J. Physiol. (Lond.) 286: 525-540.

Starke, K., and H. J. Schümann (1973) Wirkung von nifedipine auf die Funktion der sympathischen nerven des herzens. Arzneim. Forsch. 23: 193-194.

Swanson, P. D., L. Anderson, and W. C. Sthal (1975) Uptake of calcium ions by synaptosomes from rat brain. Biochim. Biophys. Acta 356: 174-185.

Takahashi, M., and A. Ogura (1983) Dihydropyridines as potent calcium channel blockers in neuronal cells. FEBS Lett. 152:
191-194.

Toll, L. (1982) Calcium antagonists. High affinity binding and inhibition of calcium transport in a clonal cell line. J. Biol. Chem. 257: 13189-13192.

Towart, R., E. Wehinger, H. Meyer, and S. Kazda (1982) The effects of nimodipine, its optical isomers and metabolites on isolated vascular smooth muscle. Arzneim. Forsch. 32: 338 346.

Trautwein, W., D. Pelzer, T. F. McDonald, and W. Osterrieder (1981) AQA-39, a new bradycardic agent which blocks myocardial calcium (Ca) channels in a frequency and voltage dependent manner. Naunyn Schmiedeberg Arch. Pharmacol. 317: 228-237.

Triggle, D. J. (1981) Calcium antagonists: Basic chemical and pharmacological aspects. In New Perspectives on Calcium Antagonists, G. B. Weiss, ed., pp. 1-18, American Physiological Society, Bethesda, MD.

Triggle, D. J. (1982) Biochemical pharmacology of calcium blockers. In Calcium Blockers: Mechanisms of Action and Clinical Applications, S. F. Flaim and R. Zelis, eds., pp. 121134, Urban and Schwarzenberg, Munich.

Van der Kloot, W., and H. Kita (1975) The effects of the calcium antagonist verapamil on muscle action potentials in the frog and crayfish and on neuromuscular transmission in the crayfish. Comp. Biochem. Physiol. 50c: 121-125.

Wada, A., N. Yanagihara, F. Izumi, S. Sakurai, and H. Kobayashi (1983) Trifluoperazine inhibits ${ }^{45} \mathrm{Ca}^{2+}$ uptake and catecholamine secretion and synthesis in adrenal medullary cells. J. Neurochem. 40: 481-486.

Weiss, G. B. (1982) Calcium release and accumulation in vascular smooth muscle. In Calcium Blockers: Mechanisms of Action and Clinical Applications, S. F. Flaim and R. Zelis, eds., pp. 65-75, Urban and Schwarzenberg, Munich. 